OPEN ACCESS

Edited by:

Eric Vivier,

INSERM U1104 Centre

D'immunologie de

Marseille-Luminy, France

Reviewed by:

Amir Horowitz,

Icahn School of Medicine at Mount

Sinai, United States

Cai Zhang,

Shandong University, China

*Correspondence:

Simona Sivori

simona.sivori@unige.it

†These authors have contributed equally to this work

Specialty section

This article was submitted to NK and Innate Lymphoid Cell Biology, a section of the journal

Frontiers in Immunology

Received: 12 April 2019

Accepted: 04 June 2019

Published: 19 June 2019

Citation:

Vitale M, Cantoni C, Della Chiesa M, Ferlazzo G, Carlomagno S, Pende D, Falco M, Pessino A, Muccio L, De Maria A, Marcenaro E, Moretta L and Sivori S (2019) An Historical Overview: The Discovery of How NK Cells Can Kill Enemies, Recruit

Defense Troops, and More.

Front. Immunol. 10:1415.

doi: 10.3389/fimmu.2019.01415

\section{An Historical Overview: The Discovery of How NK Cells Can Kill Enemies, Recruit Defense Troops, and More}

\author{
Massimo Vitale ${ }^{1 t}$, Claudia Cantoni ${ }^{2,3,4 t}$, Mariella Della Chiesa ${ }^{2,3}$, Guido Ferlazzo ${ }^{5}$, \\ Simona Carlomagno ${ }^{2}$, Daniela Pende ${ }^{1}$, Michela Falco ${ }^{4}$, Annamaria Pessino ${ }^{6}$, \\ Letizia Muccio $^{2}$, Andrea De Maria ${ }^{3,7,8}$, Emanuela Marcenaro ${ }^{2,3}$, Lorenzo Moretta ${ }^{9}$ and \\ Simona Sivori ${ }^{2,3 *}$
}

${ }^{1}$ U.O.C. Immunologia, IRCCS Ospedale Policlinico San Martino, Genoa, Italy, ${ }^{2}$ Department of Experimental Medicine, University of Genoa, Genoa, Italy, ${ }^{3}$ Centre of Excellence for Biomedical Research, University of Genoa, Genoa, Italy, ${ }^{4}$ Laboratory of Clinical and Experimental Immunology, Integrated Department of Services and Laboratories, IRCCS Istituto Giannina Gaslini, Genoa, Italy, ${ }^{5}$ Laboratory of Immunology and Biotherapy, Department of Human Pathology, University of Messina, Messina, Italy, ${ }^{6}$ Medical Oncology Unit 1, IRCCS Ospedale Policlinico San Martino, Genoa, Italy, ${ }^{7}$ Dipartimento di Scienze della Salute (DISSAL), University of Genoa, Genoa, Italy, ${ }^{8}$ Clinica Malattie Infettive, IRCCS Ospedale Policlinico San Martino, Genoa, Italy, ${ }^{9}$ Laboratory of Tumor Immunology, Department of Immunology, IRCCS Ospedale Bambino Gesù, Rome, Italy

Natural killer (NK) cells were originally defined as effector lymphocytes of innate immunity characterized by the unique ability of killing tumor and virally infected cells without any prior priming and expansion of specific clones. The "missing-self" theory, proposed by Klas Karre, the seminal discovery of the first prototypic HLA class I-specific inhibitory receptors, and, later, of the Natural Cytotoxicity Receptors (NCRs) by Alessandro Moretta, provided the bases to understand the puzzling behavior of NK cells. Actually, those discoveries proved crucial also for many of the achievements that, along the years, have contributed to the modern view of these cells. Indeed, NK cells, besides killing susceptible targets, are now known to functionally interact with different immune cells, sense pathogens using TLR, adapt their responses to the local environment, and, even, mount a sort of immunological memory. In this review, we will specifically focus on the main activating NK receptors and on their crucial role in the ever-increasing number of functions assigned to NK cells and other innate lymphoid cells (ILCs).

Keywords: human natural killer cells, innate immunity, natural cytotoxicity receptors, Toll-like receptors, activating NK receptors

\section{INTRODUCTION}

When Alessandro Moretta was appointed as Professor of Histology at the University of Genoa and started to set up a new lab and recruit people, including most of the authors of this review, the knowledge of how NK cells could exert their activity against tumors and viruses was very limited. The "missing-self" hypothesis had just been proposed by Karre and Ljunggren (1), but there was no idea on the molecular mechanisms by which NK cells could spare the "good" cells and kill the "bad" ones. Within $<10$ years, Morettas lab generated a large number of monoclonal antibodies (mAbs) that allowed the identification and characterization of many key receptors, including, 
among many others, the first-discovered Killer Ig-like receptors (KIRs) (2-4) and the Natural Cytotoxicity Receptors (NCRs) (5). These discoveries provided the mechanistic explanation of the "missing-self" theory. Indeed, they showed that NK cells could kill target cells by integrating signals from activating and inhibitory receptors, by recognizing ligands on tumor or virus-infected cells and by sensing changes in HLA class I expression (6-9).

Later studies indicated that NK cells, besides "killing the enemies," could also "incite the defense troops" by interacting with Dendritic Cells (DCs) to induce and polarize the adaptive immune response (10-12). A relevant role for given NK receptors newly identified by the Moretta's group, together with certain Toll-like receptors (TLRs), was found also in this context (1316). This field was then further investigated, revealing the quite large net of interactions that NK cells can undertake with innate (granulocytes and macrophages) and adaptive immune cells, and even stromal and tumor cells (17-24).

After this early era of major discoveries, studies on NK cells increased exponentially, revealing an extraordinarily complex world, which now comprises a number of circulating or specialized tissue-resident $\mathrm{NK}$ cell subsets (25). Some studies also showed that NK cells can adapt their function to environmental changes or even maintain memory of certain viral infections (26-30). Moreover, many of the ligands for the activating NK receptors have now been identified and demonstrated to be variably expressed by tumor or virus-infected cells $(31,32)$. Much information have been added to the mechanisms that regulate the availability and function of NK cells within tumor tissues giving hints on the possible use of NK cells in the therapy of solid tumors (33-38). Finally, the extensive studies of the KIR repertoire and the "old" data on NK/DC interaction have posed the basis for a reliable exploitation of NK cells in hematopoietic stem cell transplantation (HSCT) to cure hematologic malignancies (39-42), while the new findings on the immune checkpoints regulating $\mathrm{T}$ and $\mathrm{NK}$ cell functions have reinforced the idea of blocking HLA class I-specific NK receptors to unleash the NK cell anti-tumor potential. In this context, human/humanized antiKIR or anti-NKG2A mAbs or combinations of mAbs blocking NKG2A and the PD-1/PD-L axis are tested in animal models and clinics $(33,43-48)$.

Alessandro Moretta, who has continued his work on NK cells with immutable enthusiasm all over his life, also contributed to these latter advances in the field with many key data, spanning from the tumor escape mechanisms acting on the activating receptor expression, to the characterization of the memory-like NK cell subset, the role of activating KIRs, and the role of immune checkpoints on NK cells in tumor patients. Nevertheless, it is indubitable that the identification of the first KIRs (which will be treated in a review aside) and of many NK activating receptors represents his real landmark discovery and legacy to Science. Indeed, the characterization of these receptors impressed an acceleration of the initial research and, still now, represents the basis for many new findings on NK cells and beyond (Figure 1).

The association of different NCR splice variants with tumor tissues or with non-pathological decidua tissues, the role of NKp30, NKp46, and NKp80 in the NK-mediated cross-talk with
DCs, granulocytes, or monocytes, and the definition of NKp46 and NKp44 as markers of non-cytotoxic ILCs, are only some of the indications for the involvement of these receptors in near future studies on NK cell-based therapies against cancer, for long-standing investigations on the maternal-fetal tolerance, and, more extensively, on tissue homeostasis.

\section{NATURAL CYTOTOXICITY RECEPTORS}

Only few years after the identification of the first KIRs and of CD94/NKG2A, three non-HLA class I-specific activating receptors (namely NKp46, NKp30, and NKp44) were discovered in Alessandro Moretta's lab. These receptors, together with NKG2D, turned to be crucial for the recognition of both tumor and virus-infected cells $(5,49,50)$. They were first characterized for their functional features (i.e., their ability to induce NK cell cytolytic activity and cytokine release) (51-54) and then also at the molecular level, when the cDNAs coding for these receptors were isolated $(53,55,56)$ and the crystallographic structures were solved (57-60). NKp46, NKp30, and NKp44 were all selectively expressed on NK cells (although their expression was differently induced during activation) and revealed, since the initial studies, to be the main receptors responsible for the so-called "natural cytotoxicity" of NK cells. Thus, based on these findings, these receptors were collectively termed as Natural Cytotoxicity Receptors (NCRs), although neither the protein structure, nor the gene location gave indications for their belonging to a receptor family. Their discovery paved the way to a huge number of studies aimed at elucidating their function in both physiological and pathological conditions and characterizing the NCR/NCR ligand (NCR-L) interactions. As mentioned above, NCR expression was initially thought to be confined to NK cells, and NKp46 is still being considered a reliable NK cell-associated marker, both in humans and in mice $(61,62)$. Soon thereafter it became clear that these receptors could also be expressed in other immune cell types (63), extending their role to additional biological processes. For example, the characterization of the heterogeneous family of Innate Lymphoid Cells (ILCs) $(25,64,65)$ revealed that NKp44 is also expressed by IFN- $\gamma$-producing intraepithelial ILC1 and by a subset of ILC3 present at the epithelial/mucosal surfaces, in tonsils, and in decidua tissue (66-71). Notably, NKp44 ${ }^{\text {pos }}$ ILC3 display a unique cytokine pattern, being able to produce IL-22 following cytokine stimulation (68). In these cells, NKp44 triggering induces TNF$\alpha$ production and activates a pro-inflammatory program (72), suggesting that NKp44 could play a role in the pathogenesis of different immune-mediated disease, including psoriasis (73). In addition, $\mathrm{NCR}^{\text {pos }}\left(\mathrm{NKp} 44^{\mathrm{pos}}\right)$ ILC3 have also been detected in the lymphoid infiltrate of non-small cell lung cancer, and have been found to release pro-inflammatory cytokines following interaction with tumor cells and tumor-associated fibroblasts $(34,67,74)$. NKp46 expression has been detected in CD4 ${ }^{\text {pos }} \mathrm{T}$ lymphocytes derived from patients with Sézary syndrome, an aggressive form of cutaneous T-cell lymphoma (CTCL) (75). Notably, in these cells, NKp46 can act as an inhibitory coreceptor able to decrease CD3-mediated proliferation of Sézary 


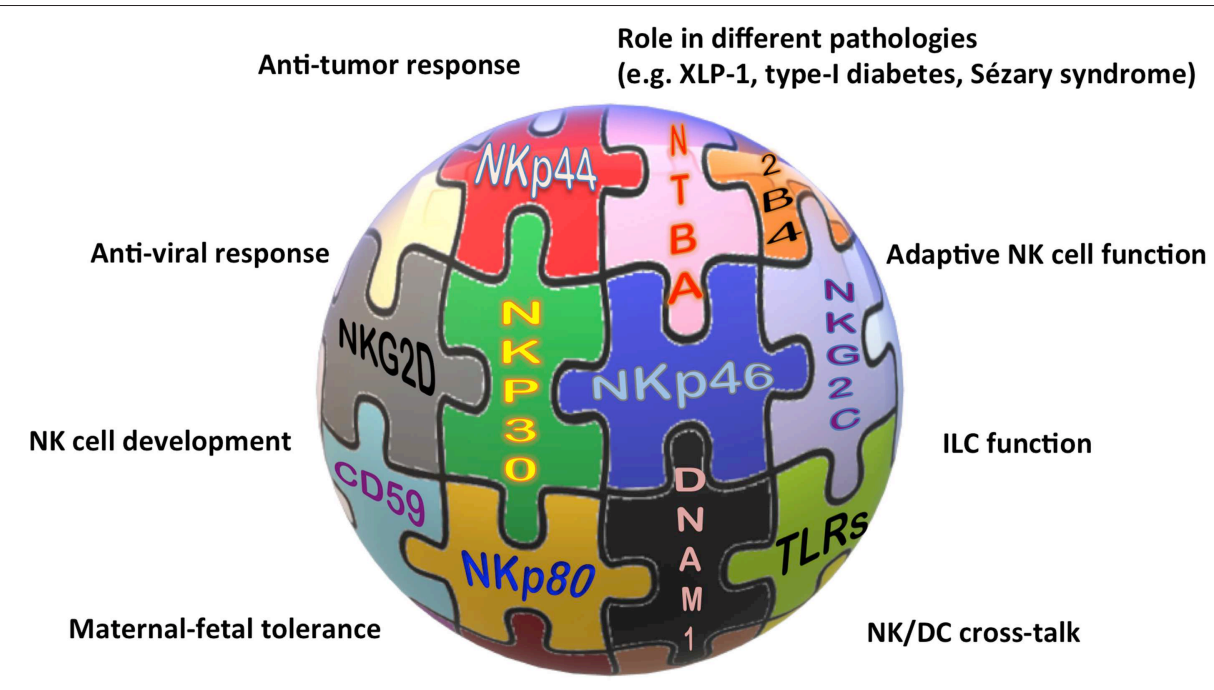

Interaction with other immune cells

FIGURE 1 | The "activating" solution of the NK cell puzzle. Different activating receptors collaborate to induce NK cell triggering in healthy and pathological conditions.

cells, and has been proposed as an additional diagnostic marker, besides KIR3DL2, for the detection of these malignant cells (76).

One of the most investigated issues about NCRs is the characterization of their ligands. Although the landscape of NCR ligands is still incomplete, a common emerging theme is the multiplicity and heterogeneity of NCR/NCR-L interactions (31, 77-80). Most NCR ligands have been shown to activate NK cell function, while others dampen NK cell activation or act as "decoy ligands" when released in soluble form (8185). The panel of cellular NCR-Ls currently includes surface glycoproteins, nuclear proteins that can be displayed at the cell surface, soluble molecules that can be either secreted, enzymatically shed, or conveyed through extracellular vesicles (82, 85-92). The expanding knowledge of NCR-Ls has opened the possibility of targeting NCR/NCR-L interactions in the context of cancer immunotherapy strategies. In addition, it has allowed the identification of several mechanisms of tumor escape related to the interaction between NK cells and malignant cells in the tumor microenvironment (22, 93-101). Finally, the importance of NK cell activity, and of NCRs in particular, in the therapeutic effect and outcome of oncolytic virotherapy has now being appreciated (102-104). NCR-Ls are also being studied as possible biomarkers in a variety of pathological conditions. Thus, a soluble form of B7-H6 (sB7-H6), an NKp30 ligand, has been demonstrated in the peritoneal fluid of ovarian cancer patients and in patients with metastatic gastrointestinal stromal tumor (GIST), neuroblastoma, or hepatocellular carcinoma (HCC) (83, $84,105,106)$. The presence of soluble BAG6/BAT3 (another NKp30-L) in the plasma of chronic lymphocytic leukemia patients was found to correlate with advanced disease stages (81). Along this line, high levels of soluble Nidogen-1, an NKp44 ligand, have been detected in the sera of patients with ovarian or lung cancer $(107,108)$.
Regarding the possibility of exploiting NCRs in antitumor approaches, it must be considered that NKp46 and NKp30 expression is down-regulated in NK cells derived from patients with different types of both hematological and nonhematological cancers $(93,109-116)$. This downmodulation leads to the impairment of NK cell anti-tumor potential and consequently to the need to develop strategies aimed at restoring NCR function (i.e., the use of cytokines, immunomodulatory drugs, anti-cancer drugs, or anti-KIR mAbs) (117-120). In addition, tumor cells themselves can become more resistant to NK cell-mediated attack by down-regulating NCR-Ls or releasing them in a soluble form (decoy ligands).

The role of NCRs stretches beyond cancer. B7-H6 is also involved in the inflammatory response: its expression is induced on monocytes following exposure to pro-inflammatory cytokines or TLR ligands, and high levels of sB7-H6 are found in the serum of patients with sepsis induced by Gram-negative bacteria (121). NK cells, in general, have been studied in different autoimmune disorders, including systemic lupus erythematosus, rheumatoid arthritis, multiple sclerosis, and type I diabetes (TID) (122-124). Focusing on NCRs, NKp46 has been shown to play a role in the pathogenesis of TID and in the destruction of normal pancreatic $\beta$ cells (125), suggesting the possibility to target this receptor through specific anti-NKp46 mAbs (126).

A few years after the NCR discovery, the existence of different splice variants of these receptors was revealed (32, 127). Thus, three alternatively spliced NKp30 isoforms were identified, characterized by distinct intracellular regions and different functional capabilities. In GIST patients the prevalence of NKp30c isoform has been associated to decreased NK cell functionality and to reduced survival (128). Along this line, a similar pattern of NKp30 isoform expression has been detected in HCC patients (106). Notably, NKp30c isoform and sB7-H6 have 
been studied in metastatic GIST patients, revealing their possible use as predictive biomarkers of disease progression and response to imatinib mesylate treatment (105). NKp44 splice variants have been studied in different neoplastic disorders, and in particular in acute myeloid leukemia patients, indicating a correlation between the prevalence of the ITIM-bearing inhibitory NKp44-1 isoform and poor survival (129). The induction of NKp44-1 expression has been also observed in decidua NK cells, driven by cytokines released in the decidua microenvironment, and could play a role in promoting tolerance toward the fetus $(127,130)$.

Among the NCRs, NKp44 is the main receptor involved in the interplay between NK cells and trophoblast cells during pregnancy $(131,132)$, and is expressed also by a subset of ILC3 and by IFN- $\gamma$-producing ILC1-like cells found in the decidua (133). Decidua NK cells represent a peculiar NK cell subset, characterized by NKp44 expression, poor cytotoxic activity, and contributing to decidua development, vascularization, and tissue building/remodeling (134-136). Notably, in these cells, NKp44 triggering has been shown to induce IP10, IL-8, and VEGF release $(132,137)$.

\section{ACTIVATING CO-RECEPTORS}

Alessandro Moretta gave fundamental contributions also to the identification and/or characterization of other surface receptors, including 2B4 (138-140), NTBA (141, 142), CD59 (143), and NKp80 (144), that play a complementary or a synergistic role with NCRs in inducing NK cell activation. Some of these molecules received great interest because of their involvement in NK cell function and development. 2B4 $(145,146)$ and NTBA (142), belonging to the signaling lymphocyte activation molecule (SLAM) family, have been shown to act as co-receptors, able to potentiate NK cell cytotoxic activity induced by the main triggering receptors, including $\operatorname{NKp} 46(140,141)$. While 2B4 receptor recognizes CD48 $(146,147)$, NTBA is involved in homophilic interactions (142). Notably, 2B4 and NTBA dysfunction was described to be associated with a severe form of immunodeficiency, the X-linked lymphoproliferative syndrome type 1 (XLP-1), caused by mutations in $S H 2 D 1 A$, the gene encoding the signaling lymphocyte activation molecule (SLAM)associated protein (SAP) (148). Interestingly, in the absence of SAP, the 2B4 and NTB-A co-receptors associate with the protein tyrosine phosphatases thus delivering inhibitory, instead of activating, signals $(141,149-151)$. This immune dysfunction is mainly responsible for the NK cell inability to kill EBV-infected B cells (B-EBV) that express CD48, resulting in extremely severe clinical consequences. A rapid diagnostic flowchart for XLP1, based on a 2B4-specific functional assay, combined with intracytoplasmic SAP staining, has been proposed (152). Moreover, the abnormal 2B4 function also influences $2 \mathrm{~B} 4$ cross-talk with other NK receptors. Indeed, inhibitory 2B4 molecule selectively blocks ITAM-dependent activating receptors, namely NCR and CD16, while it affects neither NKG2D nor DNAM-1, which do not transduce through ITAM (152). This finding explains the selective inability, shown by NK cells, to kill B-EBV cells, which highly express CD48 and are mainly recognized by NCRs. In addition, in the NK cell repertoire of XLP-1 patients, NK cells lacking any self HLA class I-specific inhibitory receptor are highly represented and fully functional, indicating that the inhibitory 2B4 participates to NK cell education (153). Interestingly, a similar role for $2 \mathrm{~B} 4$ has been described also in particular non-pathological processes. Indeed, at early stages of NK cell differentiation, when HLA class I-specific inhibitory receptors are not yet expressed, the delivery of inhibitory signals by $2 \mathrm{~B} 4$, as a consequence of the late SAP expression, renders self-tolerant immature NK cells that otherwise would be autoreactive (154). Another peculiar situation is represented by decidua NK cells, in which 2B4 functions as an inhibitory receptor due to the absence or very low levels of SAP expression (155).

CD59 has been found to associate to NKp46 and NKp30 receptors and to enhance NK cell-mediated cytotoxic activity (143).

NKp80 molecule was initially described as a co-receptor, expressed by all NK cells, and able to cooperate with triggering receptors in the induction of natural cytotoxicity (144). Later, NKp80 was found to recognize the Activation-Induced C-type Lectin (AICL), a myeloid-specific activating receptor expressed by monocytes, macrophages, and granulocytes (156). NKp80AICL interaction results in the secretion of pro-inflammatory cytokines from both cell types. In addition, it has been shown to participate in the NK cell-mediated elimination of malignant myeloid cells (156). NKp80 also plays an important role in the process of NK cell development. Indeed, it marks functionally mature NK cells developing in secondary lymphoid tissues (SLT). In particular, on the basis of NKp80 expression, two distinct subsets of SLT stage 4 cells can be distinguished: an NKp $80^{\text {neg }}$ population with both NK- and ILC3-associated features and an NKp80 ${ }^{\text {pos }}$ population with features similar to PB CD56 ${ }^{\text {bright }} \mathrm{NK}$ cells (157).

Among the surface molecules behaving as co-receptors in the activation of NK cell functions, a major role is assigned to DNAX Accessory Molecule (DNAM-1 or CD226), an adhesion molecule displaying activating function, expressed not only by all NK cells but also by T lymphocytes and monocytes (158). Alessandro Moretta's group gave an important contribution in this field with the identification of two different DNAM1 ligands, namely PVR and Nectin-2, belonging to the Nectin family (159). These molecules are widely expressed on a variety of both hematological and solid tumors (160, 161), representing suitable targets for immunotherapeutic approaches (162). The role of DNAM-1 ligands in tumor cell recognition and killing by NK cells is actually more complex, since, besides DNAM-1, also the inhibitory receptors CD96 and TIGIT can recognize PVR or PVR and Nectin-2, respectively (163, 164). Accordingly, TIGIT and CD96 have been proposed as immune checkpoints, and are becoming appealing targets for the development of antibodies to be used in combination with other immune checkpoint inhibitors with the aim of unleashing both $\mathrm{T}$ and $\mathrm{NK}$ cell cytotoxic potential against tumors $(165,166)$. 


\section{ROLE OF NK CELLS IN IMMUNE REGULATION \\ NK-DC Crosstalk}

In the late ' 90 s, it was becoming evident that innate immune cells do not act in isolation but potentiate their efficiency by interacting with each other, resulting even in the regulation of adaptive immune response. In 2001 Ralph Steinman (eventually a Nobel Laureate for the discovery of dendritic cells) visited our laboratories in Genoa and that occasion represented a starting point for a fruitful collaboration aimed at investigating the crosstalk occurring between human DCs and NK cells. As always, Prof. Moretta's insights were pivotal in all the studies carried out in that period, identifying which receptors and which subsets of these two innate immune components participate in this interaction, how this last one influences immune responses and to which extent similar stimuli (e.g., TLR ligands) are integrated by DCs and NK cells during innate immunity.

Until then, DCs were known for their critical role in initiating immune responses and priming antigen-specific $\mathrm{T}$ cell response (167), acting as sentinels in peripheral tissues, continuously sampling the environment. The dogma also foresaw that upon activation by danger signals, they up-regulated chemokine receptors and co-stimulatory molecules, which allowed them to migrate into lymph nodes and to efficiently induce $\mathrm{T}$ cell responses (167). Thus, the idea that DCs could also act as early activators of innate lymphocytes and, in turn, receive activating signals by activated NK cells, was ground-breaking in the field of innate immunity (14).

One of the relevant outcomes of NK/DC interaction is the so called "editing" of DCs, a term coined by Prof. Moretta to indicate the ability of NK cells to eliminate DCs in immature stage, and therefore bona fide tolerogenic DCs, while sparing activated/mature DCs able to efficiently induce the subsequent adaptive immune response in secondary lymphoid organs (12, $168,169)$. The protective mechanisms of mature DCs was identified in the up-regulation of HLA class I molecules, especially of the non-classical HLA-E (170), occurring upon activation of DCs by either danger signals or NK cells themselves. At the same time, also the activating receptors involved in DC recognition by NK cells were identified $(12,171)$. The relevance of NKp30 receptor in NK/DC cross-talk was not limited to the mechanisms of killing of immature DCs but extended to the maturation process of DCs upon interaction with NK cells (172).

Remarkably, this cytolytic DC editing by NK cells was identified as a NK-mediated capability of dampening the graftvs.-host disease in bone marrow transplantation (40) and graft rejection in solid organ transplantation $(173,174)$. It is noteworthy that, in case of improved skin graft rejection, NK cells were found to home to lymph nodes where they killed allogeneic DCs in a perforin-dependent manner (174).

Interestingly, and consistent with their concomitant role during the early phase of immune responses, NK cells and DCs are often able to sense similar stimuli in parallel. It was reported by Moretta's group that TLR engagement not only activates immature DCs but also renders NK cells more prone to receive triggering signals from pathogen-associated molecules, thus exerting a regulatory control on the early steps of innate immune responses against infectious agents (16), as more specifically addressed in the next paragraph.

All these studies on $\mathrm{DC} / \mathrm{NK}$ interactions indicate a critical role for $\mathrm{NK}$ cells in the initiation and regulation of immune responses and provide a strong rationale for a combined targeting of NK cells and DCs in novel immunotherapeutic strategies, harnessing this cellular cross-talk in the treatment of patients with cancer and chronic infections resistant to conventional therapies.

Alessandro Moretta's contribution to the knowledge on the molecular basis of these cellular interactions paved the way to clinical interventions exploiting $\mathrm{DC} / \mathrm{NK}$ cell cooperation. As a matter of fact, NK cell activation by DCs is particularly efficient, since DCs promote both effector functions and survival/proliferation of NK cells (169). As a whole, these basic discoveries, largely achieved under Prof. Moretta's guidance, revealed a particular translational relevance. For instance, in the field of haplo-HSCT, a beneficial role of NK cells in mediating graft-vs.-leukemia effects and in preventing GvHD was highlighted. The support provided by DCs for the proliferation/survival of NK cells is relevant also for establishing more efficient protocols for ex vivo NK cell expansion, given that NK cell-based immunotherapies are currently being reconsidered in both post-transplant hematological settings and in immunotherapy strategies for advanced solid tumors $(41,119$, 175-180).

Finally, DCs activated by NK cells are better inducers of the anti-tumor CTL response, at least in vitro, as compared with the standard mature DCs currently employed in DCbased clinical trials (181) and could therefore be considered in immunization strategies for the development of next-generation vaccines $(182,183)$.

\section{Expression and Function of TLRs on Human NK Cells}

Another field of research in which Prof. Moretta undoubtedly gave important contributions is the expression and function of TLRs in human NK cells. Indeed, in 2004 his group provided a solid experimental evidence that pathogen-associated products, known to strongly activate DCs and other innate immune cells, can also act on TLRs expressed by NK cells, inducing their activation both in terms of increased cytotoxicity and cytokine release (16). Alessandro Moretta and coworkers not only described the effect of TLR ligands on NK cell function, but also analyzed the role of TLR in the NK/DC crosstalk. This led to the concept of "NK cell-mediated editing of DCs," the "quality control" process by which NK cells select DCs that are suited for $\mathrm{T}$ cell priming. The capability of TLR agonists of potentiating NK cell function was further defined in subsequent studies (184-193). Thus, in 2010 a peculiar cooperation between TLR9 and KIR3DL2 in inducing triggering of NK cell function upon treatment with CpG-ODN (TLR9 ligand) was described (194, 195). This study revealed that KIR3DL2 can bind CpGODNs at the NK cell surface and shuttle them to endosomes 
where TLR9 is localized, thus resulting in sharp down-regulation of KIR3DL2 surface expression and in TLR9-mediated induction of cytokine release. Moreover, it was demonstrated that the KIR Ig-domain involved in the direct recognition of CpGODN is represented by D0. Since this domain was hypothesized to be expressed by the putative ancestral mammalian KIR, these data suggested that, originally, certain KIRs could exert a function different from recognition of HLA class I molecules. Moreover, this newly defined functional capability of KIR3DL2 provided an important clue to understand the driving forces that led to the conservation of the KIR3DL2-encoding gene in all haplotypes, despite the low frequency, in the human population, of HLA- $\mathrm{A}^{*} 03$ or $-\mathrm{A}^{*} 11$ alleles (i.e., the ligands of KIR3DL2). Furthermore, in the Sézary Syndrome, in which KIR3DL2 represents a specific marker for the assessment of circulating tumor burden and for patient follow-up (76), CpGODN has been shown to promote not only the internalization of KIR3DL2 receptor but also the generation of apoptotic signals (196). Thus, CpG-ODN may exert a direct anti-tumor effect on Sézary cells through binding to KIR3DL2. In this context, a good clinical response without major side effects was observed upon class-B CpG-ODN subcutaneous administration in CTCL patients (197). CpG-DNA and other TLR agonists have been also explored as adjuvants for immunotherapy. Indeed, many clinical trials based on the use of CpG-ODNs as immunotherapeutic agents revealed that $\mathrm{CpG}-\mathrm{ODNs}$ can promote Th1 immune responses and may be used in combination with chemotherapy to induce potent anti-tumor immune responses with relevant clinical benefits $(186,198,199)$.

\section{NK Cell Subsets in Anti-virus Responses}

Besides cancer and other diseases, NCRs also contribute to the NK cell-mediated control of viral infections through the recognition of virus-infected cells. Indeed, the first characterized NCR-Ls were of viral origin, namely influenza virus hemagglutinins $(200,201)$. Later on, additional viral ligands were identified and, in most cases, they were shown to induce NK cell activation following NCR engagement $(31,78,202)$. It is of note, however, that some viral NCR-Ls can inhibit NCR functions, representing a possible immune evasion strategy (203). It has been very recently demonstrated in mouse that NK cells may play a regulatory role during acute and

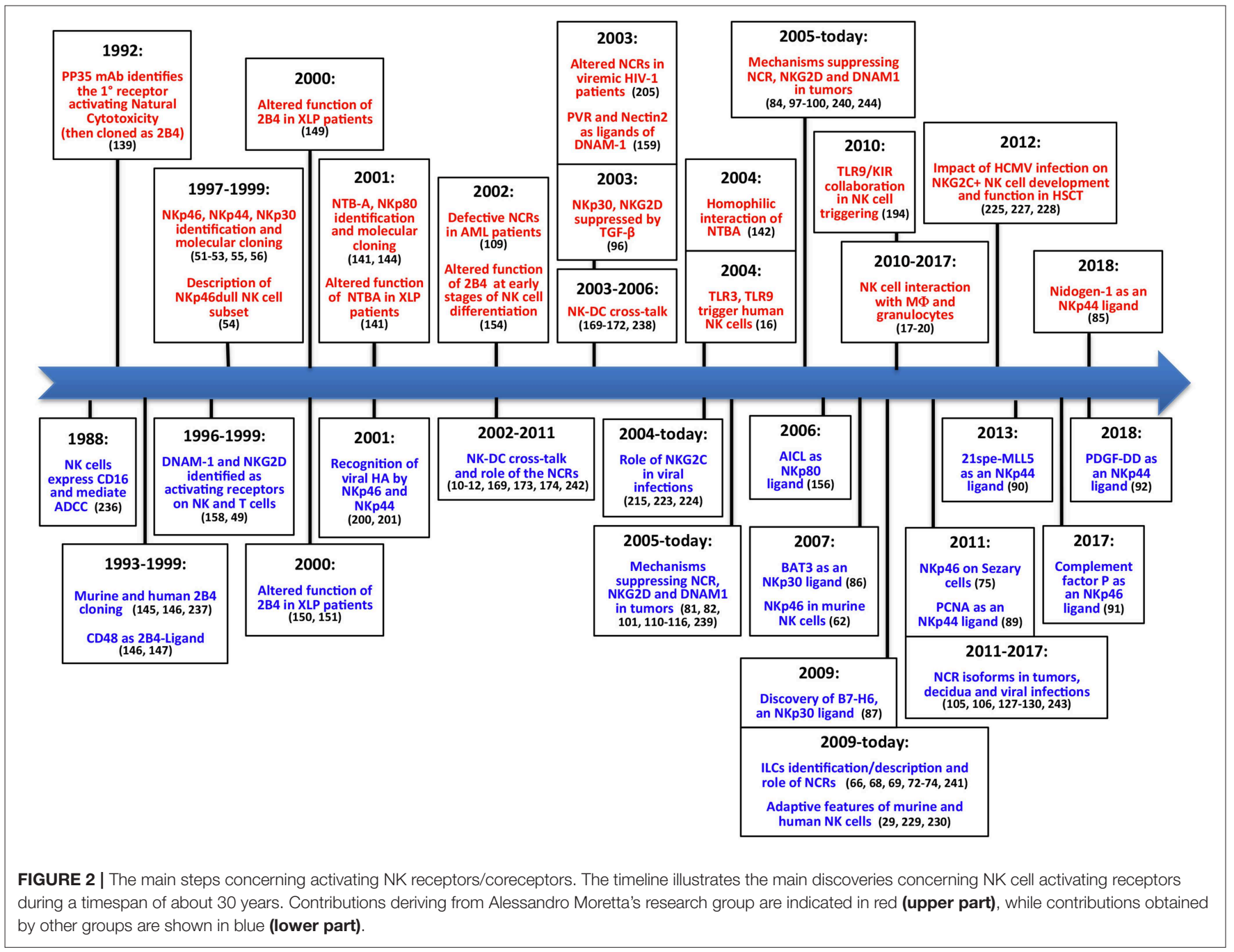


chronic lymphocytic choriomeningitis virus (LCMV) infection through the NKp46-mediated killing of LCMV-specific CD8 T cells (204).

In recent years Prof. Moretta and his co-workers gave major contributions to broaden our knowledge on NK cell diversity and functional specialization. This occurred primarily thanks to studies focused on NK cell-mediated responses to virus infections. Fundamental results came from the characterization of NK cells in patients chronically infected by HIV that revealed a deep functional impairment of NK cells likely determining their scarce capacity to efficiently control this virus. In this context, the relevance of NCR contribution to the course of HIV infection became clear when their reduced expression on NK cells in viraemic HIV-infected patients was demonstrated $(205,206)$. The NCR role in anti-viral response was also supported by the demonstration that NKp46 and NKp30 inducibility exerted a protective role in HIV-infected patients with excellent control not only of virus replication but, more importantly, also of retroviral reservoir $(207,208)$. Outside the HIV field, the study of NCR expression on NK cells similarly provided compelling evidence of their involvement in the response to acute $\mathrm{HCV}$ infection (209), and in HCV eradication in treated chronic carriers $(210,211)$. Interestingly, in chronically infected HIV patients the accumulation of a dysfunctional NK cell subset, virtually absent in healthy subjects, characterized by an aberrant $\mathrm{CD} 56^{\text {neg }} \mathrm{CD} 16^{\text {bright }}$ surface signature $(205,212,213)$ and defective DC editing was observed (214). This unusual population has been subsequently identified in several other pathological conditions including viral infections and immune deficiencies, in which these cells are responsible for an altered response to a chronic immune activation (215-219).

Besides HIV, a fundamental role in shaping NK cell repertoire and function has been described for CMV infection (220-222). Based on the pioneering studies by M. LopezBotet who first described the imprinting exerted by CMV on NK cells $(223,224)$, Alessandro Moretta contributed to identify CMV infection as a key driving force promoting the differentiation of functionally and phenotypically skewed NK cells with several studies conducted in HSCT recipients (225228). In this setting, CMV infection/reactivation could induce not just NK cell maturation toward highly differentiated stages (characterized by the expression of CD94/NKG2C or activating KIRs), but also the unexpected acquisition of immunological memory. Indeed, NK cells maturing in CMV-reactivating patients share features with adaptive immune cells, such as longterm persistence, virus-induced clonal expansion, and epigenetic modifications (227, 229-234).

This anti-paradigmatic concept of memory or adaptive NK cells, to which Prof. Moretta contributed, holds important translational promise as this NK cell population characterized by longevity and superior ADCC ability, represents a potential tool for novel immunotherapeutic anti-cancer strategies, namely antibody-based tumor immunotherapies and generation of long-living anti-tumor CAR-NK cells $(179,235)$.

\section{Tumor cell killing by:}

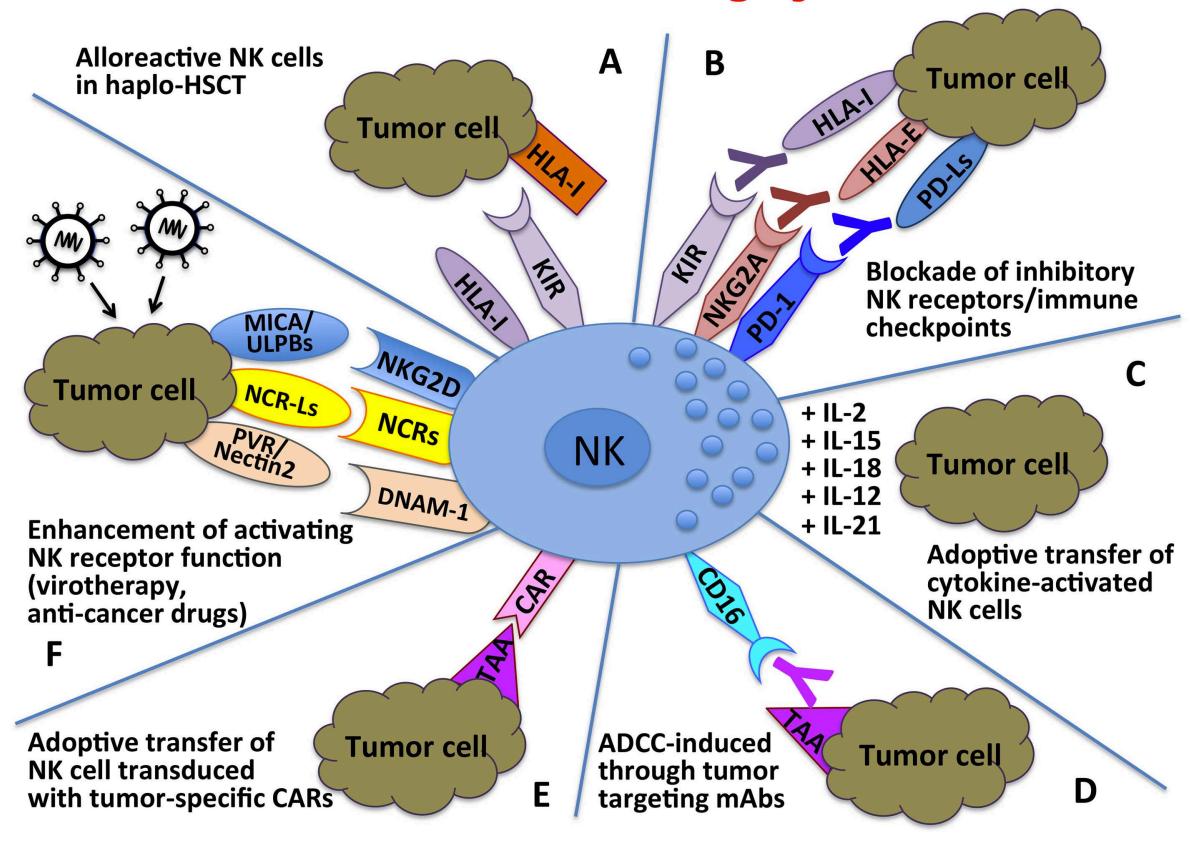

FIGURE 3 | Clinical applications of NK cells in the immunotherapy against tumors. In haplo-HSCT, alloreactive NK cells can kill residual leukemic cells (A); mAbs directed against immune checkpoints can unleash/restore NK cell anti-tumor activity (B); tumor cell killing can be enhanced by adoptive transfer of cytokine-activated NK cells (C) or NK cells transduced with tumor-specific Chimeric Antigen Receptors (CARs) (E); tumor targeting mAbs can induce NK cell-mediated ADCC (D); activating NK receptor function can be potentiated through oncolytic virotherapy or the use of anti-cancer drugs (F). 


\section{NK CELL-BASED CLINICAL APPLICATIONS}

Altogether, these discoveries in the field of NK cell biology (Figure 2) (236-243) paved the way to the exploitation of these cells in different anti-tumor therapeutic approaches (Figure 3). Over the years important achievements have been obtained, and promising novel strategies have been designed. The most advanced clinical application exploiting the NK cell anti-tumor potential is in the field of haplo-identical HSCT $(40-42,235)$, in which donor-derived alloreactive NK cells (i.e., unable to recognize recipient HLA class I molecules) can exert a potent anti-leukemia effect. Moreover, the adoptive transfer of NK cells, in an autologous or allogeneic setting, can be pursued following NK cell activation and expansion with cytokines (118-120). The blockade of HLA class I-specific inhibitory receptors using human/humanized mAbs can be used to enhance killing of HLA class $\mathrm{I}^{\text {pos }}$ tumor cells. These $\mathrm{mAbs}$ can be used in combination with mAbs interfering with the PD-1/PD-L axis, as PD-1 can be expressed by human NK cells $(46,244)$. Another clinical approach is represented by the induction of ADCC against tumor cells by the use of antibodies specific for tumor-associated antigens (119).

More recently, the CAR technology, originally designed for $\mathrm{T}$ lymphocytes, has been applied also to NK cells, with promising results in the therapy of both hematological and solid tumors $(118,120)$. The ever-growing knowledge of activating NK receptor/ligand interactions is being applied in several strategies aimed to potentiate triggering signals through virotherapy or by the use of anti-cancer drugs capable of enhancing the expression of activating ligands on tumor cells and activating receptors on NK cells $(102,117)$. In conclusion, NK cell-based therapy used in combination with conventional therapeutic protocols could

\section{REFERENCES}

1. Ljunggren HG, Karre K. In search of the 'missing self': MHC molecules and NK cell recognition. Immunol Today. (1990) 11:237-44. doi: 10.1016/0167-5699(90)90097-S

2. Moretta A, Bottino C, Vitale M, Pende D, Biassoni R, Mingari MC, et al. Receptors for HLA class-I molecules in human natural killer cells. Annu Rev Immunol. (1996) 14:619-48. doi: 10.1146/annurev.immunol.14.1.619

3. Moretta A, Biassoni R, Bottino C, Pende D, Vitale M, Poggi A, et al. Major histocompatibility complex class I-specific receptors on human natural killer and T lymphocytes. Immunol Rev. (1997) 155:10517. doi: 10.1111/j.1600-065X.1997.tb00943.x

4. Wagtmann N, Rajagopalan S, Winter CC, Peruzzi M, Long EO. Killer cell inhibitory receptors specific for HLA-C and HLA-B identified by direct binding and by functional transfer. Immunity. (1995) 3:8019. doi: 10.1016/1074-7613(95)90069-1

5. Moretta A, Bottino C, Vitale M, Pende D, Cantoni C, Mingari $\mathrm{MC}$, et al. Activating receptors and coreceptors involved in human natural killer cell-mediated cytolysis. Annu Rev Immunol. (2001) 19:197223. doi: 10.1146/annurev.immunol.19.1.197

6. Long EO, Burshtyn DN, Clark WP, Peruzzi M, Rajagopalan S, Rojo S, et al. Killer cell inhibitory receptors: diversity, specificity, and function. Immunol Rev. (1997) 155:135-44. doi: 10.1111/j.1600-065X.1997.tb00946.x

7. Colonna M. Specificity and function of immunoglobulin superfamily NK cell inhibitory and stimulatory receptors. Immunol Rev. (1997) 155:12733. doi: 10.1111/j.1600-065X.1997.tb00945.x become more and more a powerful tool to be used in the cure of cancer.

\section{CONCLUDING REMARKS}

By revisiting the discovery of the most important NK receptors and considering the technical approaches available at that time, one might have the impression that it has been simple to obtain those results. However, experienced researchers know that, actually, relevant pieces of information leading to a new discovery must be selected from an initially confusing, and often contradictory, mass of data. Alessandro had this ability, common to many gifted scientists, but he was also endowed with the uncommon talent of catching essential information and rendering simple what actually is very complex. We think that this has been the true and most important lesson for all of us and, undoubtedly, a major legacy for Immunology and Medicine.

\section{AUTHOR CONTRIBUTIONS}

All authors listed have made a substantial, direct and intellectual contribution to the work, and approved it for publication.

\section{FUNDING}

Supported by the following grants: Fondazione AIRC 5X1000, 2018 Project Code 21147 (LoM and SS), Fondazione AIRC IG 2017, Project Code 19920 (LoM), Fondazione AIRC IG 2017 Project Code 20312 (SS), Fondazione AIRC IG 2015, Project Code 16764 (DP), AIRC IG 2014 project no. 15428 (MV), and 5X1000 Min. Sal. 2013 (MV); LeM is a recipient of a fellowship awarded by Federazione Italiana Ricerca sul Cancro (FIRC).

8. Parham P. MHC class I molecules and KIRs in human history, health and survival. Nat Rev Immunol. (2005) 5:201-14. doi: 10.1038/nri1570

9. Lanier LL. Natural killer cells: from no receptors to too many. Immunity. (1997) 6:371-8. doi: 10.1016/S1074-7613(00)80280-0

10. Piccioli D, Sbrana S, Melandri E, Valiante NM. Contact-dependent stimulation and inhibition of dendritic cells by natural killer cells. J Exp Med. (2002) 195:335-41. doi: 10.1084/jem.20010934

11. Gerosa F, Baldani-Guerra B, Nisii C, Marchesini V, Carra G, Trinchieri G. Reciprocal activating interaction between natural killer cells and dendritic cells. J Exp Med. (2002) 195:327-33. doi: 10.1084/jem.20010938

12. Ferlazzo G, Tsang ML, Moretta L, Melioli G, Steinman RM, Munz C. Human dendritic cells activate resting natural killer (NK) cells and are recognized via the NKp30 receptor by activated NK cells. J Exp Med. (2002) 195:343-51. doi: 10.1084/jem.20011149

13. Sivori S, Carlomagno S, Pesce S, Moretta A, Vitale M, Marcenaro E. TLR/NCR/KIR: which one to use and when? Front Immunol. (2014) 5:105. doi: 10.3389/fimmu.2014.00105

14. Moretta A. Natural killer cells and dendritic cells: rendezvous in abused tissues. Nat Rev Immunol. (2002) 2:957-64. doi: 10.1038/nri956

15. Della Chiesa M, Sivori S, Castriconi R, Marcenaro E, Moretta A. Pathogen-induced private conversations between natural killer and dendritic cells. Trends Microbiol. (2005) 13:128-36. doi: 10.1016/j.tim.2005. 01.006

16. Sivori S, Falco M, Della Chiesa M, Carlomagno S, Vitale M, Moretta $\mathrm{L}$, et al. CpG and double-stranded RNA trigger human NK cells by Toll-like receptors: induction of cytokine release and cytotoxicity against 
tumors and dendritic cells. Proc Natl Acad Sci USA. (2004) 101:1011621. doi: 10.1073 /pnas. 0403744101

17. Thoren FB, Riise RE, Ousback J, Della Chiesa M, Alsterholm M, Marcenaro E, et al. Human NK Cells induce neutrophil apoptosis via an NKp46- and Fas-dependent mechanism. J Immunol. (2012) 188:166874. doi: 10.4049/jimmunol.1102002

18. Riise RE, Bernson E, Aurelius J, Martner A, Pesce S, Della Chiesa M, et al. TLR-stimulated neutrophils instruct NK cells to trigger dendritic cell maturation and promote adaptive T cell responses. J Immunol. (2015) 195:1121-8. doi: 10.4049/jimmunol.1500709

19. Bellora F, Castriconi R, Dondero A, Reggiardo G, Moretta L, Mantovani A, et al. The interaction of human natural killer cells with either unpolarized or polarized macrophages results in different functional outcomes. Proc Natl Acad Sci USA. (2010) 107:21659-64. doi: 10.1073/pnas.1007654108

20. Pesce S, Thoren FB, Cantoni C, Prato C, Moretta L, Moretta A, et al. The innate immune cross talk between NK cells and eosinophils is regulated by the interaction of natural cytotoxicity receptors with eosinophil surface ligands. Front Immunol. (2017) 8:510. doi: 10.3389/fimmu.2017. 00510

21. Mattiola I, Pesant M, Tentorio PF, Molgora M, Marcenaro E, Lugli E, et al. Priming of human resting NK cells by autologous M1 macrophages via the engagement of IL-1beta, IFN-beta, and IL-15 Pathways. J Immunol. (2015) 195:2818-28. doi: 10.4049/jimmunol.1500325

22. Vitale M, Cantoni C, Pietra G, Mingari MC, Moretta L. Effect of tumor cells and tumor microenvironment on NK-cell function. Eur J Immunol. (2014) 44:1582-92. doi: 10.1002/eji.201344272

23. Martin-Fontecha A, Thomsen LL, Brett S, Gerard C, Lipp M, Lanzavecchia A, et al. Induced recruitment of NK cells to lymph nodes provides IFN-gamma for $\mathrm{T}(\mathrm{H}) 1$ priming. Nat Immunol. (2004) 5:1260-5. doi: 10.1038/ni1138

24. Ardolino M, Zingoni A, Cerboni C, Cecere F, Soriani A, Iannitto ML, et al. DNAM-1 ligand expression on Ag-stimulated T lymphocytes is mediated by ROS-dependent activation of DNAdamage response: relevance for NK-T cell interaction. Blood. (2011) 117:4778-86. doi: 10.1182/blood-2010-08-300954

25. Freud AG, Mundy-Bosse BL, Yu J, Caligiuri MA. The broad spectrum of human natural killer cell diversity. Immunity. (2017) 47:820-33. doi: 10.1016/j.immuni.2017.10.008

26. Della Chiesa M, Sivori S, Carlomagno S, Moretta L, Moretta A. Activating KIRs and NKG2C in viral infections: toward NK cell memory? Front Immunol. (2015) 6:573. doi: 10.3389/fimmu.2015. 00573

27. Della Chiesa M, Marcenaro E, Sivori S, Carlomagno S, Pesce S, Moretta A. Human NK cell response to pathogens. Semin Immunol. (2014) 26:15260. doi: 10.1016/j.smim.2014.02.001

28. Muntasell A, Vilches C, Angulo A, Lopez-Botet M. Adaptive reconfiguration of the human NK-cell compartment in response to cytomegalovirus: a different perspective of the host-pathogen interaction. Eur J Immunol. (2013) 43:1133-41. doi: 10.1002/eji.201243117

29. Sun JC, Beilke JN, Lanier LL. Adaptive immune features of natural killer cells. Nature. (2009) 457:557-61. doi: 10.1038/nature07665

30. Vivier E, Raulet DH, Moretta A, Caligiuri MA, Zitvogel L, Lanier LL, et al. Innate or adaptive immunity? The example of natural killer cells. Science. (2011) 331:44-9. doi: 10.1126/science.1198687

31. Kruse PH, Matta J, Ugolini S, Vivier E. Natural cytotoxicity receptors and their ligands. Immunol Cell Biol. (2014) 92:221-9. doi: 10.1038/icb. 2013.98

32. Pazina T, Shemesh A, Brusilovsky M, Porgador A, Campbell KS. Regulation of the functions of natural cytotoxicity receptors by interactions with diverse ligands and alterations in splice variant expression. Front Immunol. (2017) 8:369. doi: 10.3389/fimmu.2017.00369

33. Sivori S, Vacca P, Del Zotto G, Munari E, Mingari MC, Moretta L. Human NK cells: surface receptors, inhibitory checkpoints, and translational applications. Cell Mol Immunol. (2019) 16:430-41. doi: 10.1038/s41423-019-0206-4

34. Chiossone L, Dumas PY, Vienne M, Vivier E. Natural killer cells and other innate lymphoid cells in cancer. Nat Rev Immunol. (2018) 18:67188. doi: 10.1038/s41577-018-0061-z
35. Pietra G, Vitale C, Pende D, Bertaina A, Moretta F, Falco M, et al. Human natural killer cells: news in the therapy of solid tumors and high-risk leukemias. Cancer Immunol Immunother. (2016) 65:46576. doi: 10.1007/s00262-015-1744-y

36. Tallerico R, Garofalo C, Carbone E. A new biological feature of natural killer cells: the recognition of solid tumor-derived cancer stem cells. Front Immunol. (2016) 7:179. doi: 10.3389/fimmu.2016.00179

37. Stabile H, Fionda C, Gismondi A, Santoni A. Role of distinct natural killer cell subsets in anticancer response. Front Immunol. (2017) 8:293. doi: 10.3389/fimmu.2017.00293

38. Mehta RS, Rezvani K. Chimeric antigen receptor expressing natural killer cells for the immunotherapy of cancer. Front Immunol. (2018) 9:283. doi: 10.3389/fimmu.2018.00283

39. Moretta L, Pietra G, Montaldo E, Vacca P, Pende D, Falco M, et al. Human NK cells: from surface receptors to the therapy of leukemias and solid tumors. Front Immunol. (2014) 5:87. doi: 10.3389/fimmu.2014.00087

40. Ruggeri L, Capanni M, Urbani E, Perruccio K, Shlomchik WD, Tosti A, et al. Effectiveness of donor natural killer cell alloreactivity in mismatched hematopoietic transplants. Science. (2002) 295:2097-100. doi: 10.1126/science.1068440

41. Pende D, Marcenaro S, Falco M, Martini S, Bernardo ME, Montagna D, et al. Anti-leukemia activity of alloreactive NK cells in KIR ligand-mismatched haploidentical HSCT for pediatric patients: evaluation of the functional role of activating KIR and redefinition of inhibitory KIR specificity. Blood. (2009) 113:3119-29. doi: 10.1182/blood-2008-06-164103

42. Cooley S, Trachtenberg E, Bergemann TL, Saeteurn K, Klein J, Le CT, et al. Donors with group B KIR haplotypes improve relapse-free survival after unrelated hematopoietic cell transplantation for acute myelogenous leukemia. Blood. (2009) 113:726-32. doi: 10.1182/blood-2008-07-171926

43. Benson DM, Jr., Bakan CE, Zhang S, Collins SM, Liang J, Srivastava S, et al. IPH2101, a novel anti-inhibitory KIR antibody, and lenalidomide combine to enhance the natural killer cell versus multiple myeloma effect. Blood. (2011) 118:6387-91. doi: 10.1182/blood-2011-06-360255

44. Pardoll DM. The blockade of immune checkpoints in cancer immunotherapy. Nat Rev Cancer. (2012) 12:252-64. doi: 10.1038/nrc3239

45. Hughes PE, Caenepeel S, Wu LC. Targeted therapy and checkpoint immunotherapy combinations for the treatment of cancer. Trends Immunol. (2016) 37:462-76. doi: 10.1016/j.it.2016.04.010

46. Andre P, Denis C, Soulas C, Bourbon-Caillet C, Lopez J, Arnoux T, et al. Anti-NKG2A mAb Is a checkpoint inhibitor that promotes anti-tumor immunity by unleashing both T and NK cells. Cell. (2018) 175:1731-43 e13. doi: 10.1016/j.cell.2018.10.014

47. Sanchez-Correa B, Lopez-Sejas N, Duran E, Labella F, Alonso C, Solana $\mathrm{R}$, et al. Modulation of NK cells with checkpoint inhibitors in the context of cancer immunotherapy. Cancer Immunol Immunother. (2019) 68:86170. doi: 10.1007/s00262-019-02336-6

48. Morvan MG, Lanier LL. NK cells and cancer: you can teach innate cells new tricks. Nat Rev Cancer. (2016) 16:7-19. doi: 10.1038/nrc.2015.5

49. Bauer S, Groh V, Wu J, Steinle A, Phillips JH, Lanier LL, et al. Activation of NK cells and T cells by NKG2D, a receptor for stress-inducible MICA. Science. (1999) 285:727-9. doi: 10.1126/science.285.5428.727

50. El-Gazzar A, Groh V, Spies T. Immunobiology and conflicting roles of the human NKG2D lymphocyte receptor and its ligands in cancer. J Immunol. (2013) 191:1509-15. doi: 10.4049/jimmunol.1301071

51. Sivori S, Vitale M, Morelli L, Sanseverino L, Augugliaro R, Bottino C, et al. $\mathrm{p} 46$, a novel natural killer cell-specific surface molecule that mediates cell activation. J Exp Med. (1997) 186:1129-36. doi: 10.1084/jem.186.7.1129

52. Vitale M, Bottino C, Sivori S, Sanseverino L, Castriconi R, Marcenaro E, et al. NKp44, a novel triggering surface molecule specifically expressed by activated natural killer cells, is involved in non-major histocompatibility complex-restricted tumor cell lysis. J Exp Med. (1998) 187:206572. doi: $10.1084 /$ jem.187.12.2065

53. Pende D, Parolini S, Pessino A, Sivori S, Augugliaro R, Morelli L, et al. Identification and molecular characterization of NKp30, a novel triggering receptor involved in natural cytotoxicity mediated by human natural killer cells. J Exp Med. (1999) 190:1505-16. doi: 10.1084/jem.190.10.1505

54. Sivori S, Pende D, Bottino C, Marcenaro E, Pessino A, Biassoni R, et al. NKp46 is the major triggering receptor involved in the natural cytotoxicity 
of fresh or cultured human NK cells. Correlation between surface density of NKp46 and natural cytotoxicity against autologous, allogeneic or xenogeneic target cells. Eur J Immunol. (1999) 29:1656-66.

55. Pessino A, Sivori S, Bottino C, Malaspina A, Morelli L, Moretta L, et al. Molecular cloning of NKp46: a novel member of the immunoglobulin superfamily involved in triggering of natural cytotoxicity. J Exp Med. (1998) 188:953-60. doi: 10.1084/jem.188.5.953

56. Cantoni C, Bottino C, Vitale M, Pessino A, Augugliaro R, Malaspina A, et al. NKp44, a triggering receptor involved in tumor cell lysis by activated human natural killer cells, is a novel member of the immunoglobulin superfamily. $J$ Exp Med. (1999) 189:787-96. doi: 10.1084/jem.189.5.787

57. Cantoni C, Ponassi M, Biassoni R, Conte R, Spallarossa A, Moretta A, et al. The three-dimensional structure of the human NK cell receptor NKp44, a triggering partner in natural cytotoxicity. Structure. (2003) 11:72534. doi: 10.1016/S0969-2126(03)00095-9

58. Ponassi M, Cantoni C, Biassoni R, Conte R, Spallarossa A, Pesce A, et al. Structure of the human NK cell triggering receptor NKp46 ectodomain. Biochem Biophys Res Commun. (2003) 309:317-23. doi: 10.1016/j.bbrc.2003.08.007

59. Li Y, Wang Q, Mariuzza RA. Structure of the human activating natural cytotoxicity receptor NKp30 bound to its tumor cell ligand B7-H6. J Exp Med. (2011) 208:703-14. doi: 10.1084/jem.20102548

60. Joyce MG, Tran P, Zhuravleva MA, Jaw J, Colonna M, Sun PD. Crystal structure of human natural cytotoxicity receptor NKp30 and identification of its ligand binding site. Proc Natl Acad Sci USA. (2011) 108:62238. doi: 10.1073/pnas.1100622108

61. Biassoni R, Pessino A, Bottino C, Pende D, Moretta L, Moretta A. The murine homologue of the human NKp46, a triggering receptor involved in the induction of natural cytotoxicity. Eur J Immunol. (1999) 29:1014-20.

62. Walzer $T$, Blery M, Chaix J, Fuseri $N$, Chasson L, Robbins SH, et al. Identification, activation, and selective in vivo ablation of mouse NK cells via NKp46. Proc Natl Acad Sci USA. (2007) 104:33849. doi: 10.1073/pnas.0609692104

63. Hudspeth K, Silva-Santos B, Mavilio D. Natural cytotoxicity receptors: broader expression patterns and functions in innate and adaptive immune cells. Front Immunol. (2013) 4:69. doi: 10.3389/fimmu.2013.00069

64. Vivier E, Artis D, Colonna M, Diefenbach A, Di Santo JP, Eberl G, et al. Innate lymphoid cells: 10 years on. Cell. (2018) 174:105466. doi: 10.1016/j.cell.2018.07.017

65. Vacca P, Munari E, Tumino N, Moretta F, Pietra G, Vitale M, et al. Human natural killer cells and other innate lymphoid cells in cancer: friends or foes? Immunol Lett. (2018) 201:14-9. doi: 10.1016/j.imlet.2018.11.004

66. Fuchs A, Vermi W, Lee JS, Lonardi S, Gilfillan S, Newberry RD, et al. Intraepithelial type 1 innate lymphoid cells are a unique subset of IL12- and IL-15-responsive IFN-gamma-producing cells. Immunity. (2013) 38:769-81. doi: 10.1016/j.immuni.2013.02.010

67. Simoni Y, Newell EW. Toward meaningful definitions of innate-lymphoidcell subsets. Immunity. (2017) 46:760-1. doi: 10.1016/j.immuni.2017.04.026

68. Cella M, Fuchs A, Vermi W, Facchetti F, Otero K, Lennerz JK, et al. A human natural killer cell subset provides an innate source of IL-22 for mucosal immunity. Nature. (2009) 457:722-5. doi: 10.1038/nature07537

69. Hoorweg K, Peters CP, Cornelissen F, Aparicio-Domingo P, Papazian $\mathrm{N}$, Kazemier G, et al. Functional differences between human NKp44and $\mathrm{NKp}_{4} 4^{+}$RORC $^{+}$innate lymphoid cells. Front Immunol. (2012) 3:72. doi: $10.3389 /$ fimmu.2012.00072

70. Killig $M$, Glatzer $T$, Romagnani C. Recognition strategies of group 3 innate lymphoid cells. Front Immunol. (2014) 5:142. doi: $10.3389 /$ fimmu.2014.00142

71. Vacca P, Vitale C, Munari E, Cassatella MA, Mingari MC, Moretta L. Human innate lymphoid cells: their functional and cellular interactions in decidua. Front Immunol. (2018) 9:1897. doi: 10.3389/fimmu.2018.01897

72. Glatzer T, Killig M, Meisig J, Ommert I, Luetke-Eversloh M, Babic M, et al. $\mathrm{ROR} \gamma \mathrm{t}^{+}$innate lymphoid cells acquire a proinflammatory program upon engagement of the activating receptor NKp44. Immunity. (2013) 38:122335. doi: $10.1016 /$ j.immuni.2013.05.013

73. Villanova F, Flutter B, Tosi I, Grys K, Sreeneebus H, Perera GK, et al. Characterization of innate lymphoid cells in human skin and blood demonstrates increase of NKp44+ ILC3 in psoriasis. J Invest Dermatol. (2014) 134:984-91. doi: 10.1038/jid.2013.477
74. Carrega P, Loiacono F, Di Carlo E, Scaramuccia A, Mora M, Conte R, et al. NCR ${ }^{+}$ILC3 concentrate in human lung cancer and associate with intratumoral lymphoid structures. Nat Commun. (2015) 6:8280. doi: $10.1038 /$ ncomms 9280

75. Bensussan A, Remtoula N, Sivori S, Bagot M, Moretta A, Marie-Cardine A. Expression and function of the natural cytotoxicity receptor NKp46 on circulating malignant CD4+ T lymphocytes of Sezary syndrome patients. $J$ Invest Dermatol. (2011) 131:969-76. doi: 10.1038/jid.2010.404

76. Bagot M, Moretta A, Sivori S, Biassoni R, Cantoni C, Bottino $\mathrm{C}$, et al. CD4+ cutaneous T-cell lymphoma cells express the p140-killer cell immunoglobulin-like receptor. Blood. (2001) 97:1388-91. doi: 10.1182/blood.V97.5.1388

77. Lam RA, Chwee JY, Le Bert N, Sauer M, Pogge von Strandmann E, Gasser S. Regulation of self-ligands for activating natural killer cell receptors. Ann Med. (2013) 45:384-94. doi: 10.3109/07853890.2013.792495

78. Koch J, Steinle A, Watzl C, Mandelboim O. Activating natural cytotoxicity receptors of natural killer cells in cancer and infection. Trends Immunol. (2013) 34:182-91. doi: 10.1016/j.it.2013.01.003

79. Brusilovsky M, Radinsky O, Yossef R, Campbell KS, Porgador A. Carbohydrate-mediated modulation of NK cell receptor function: structural and functional influences of heparan sulfate moieties expressed on NK cell surface. Front Oncol. (2014) 4:185. doi: 10.3389/fonc.2014.00185

80. Horton NC, Mathew PA. NKp44 and natural cytotoxicity receptors as damage-associated molecular pattern recognition receptors. Front Immunol. (2015) 6:31. doi: 10.3389/fimmu.2015.00031

81. Reiners KS, Topolar D, Henke A, Simhadri VR, Kessler J, Sauer M, et al. Soluble ligands for NK cell receptors promote evasion of chronic lymphocytic leukemia cells from NK cell anti-tumor activity. Blood. (2013) 121:3658-65. doi: 10.1182/blood-2013-01-476606

82. Schlecker E, Fiegler N, Arnold A, Altevogt P, Rose-John S, Moldenhauer G, et al. Metalloprotease-mediated tumor cell shedding of B7-H6, the ligand of the natural killer cell-activating receptor NKp30. Cancer Res. (2014) 74:3429-40. doi: 10.1158/0008-5472.CAN-13-3017

83. Semeraro M, Rusakiewicz S, Minard-Colin V, Delahaye NF, Enot D, Vely F, et al. Clinical impact of the NKp30/B7-H6 axis in high-risk neuroblastoma patients. Sci Transl Med. (2015) 7:283ra55. doi: 10.1126/scitranslmed.aaa2327

84. Pesce S, Tabellini G, Cantoni C, Patrizi O, Coltrini D, Rampinelli F, et al. B7-H6-mediated downregulation of NKp30 in NK cells contributes to ovarian carcinoma immune escape. Oncoimmunology. (2015) 4:e1001224. doi: 10.1080/2162402X.2014.1001224

85. Gaggero S, Bruschi M, Petretto A, Parodi M, Zotto GD, Lavarello C, et al. Nidogen-1 is a novel extracellular ligand for the NKp44 activating receptor. Oncoimmunology. (2018) 7:e1470730. doi: 10.1080/2162402X.2018.14 70730

86. Pogge von Strandmann E, Simhadri VR, von Tresckow B, Sasse S, Reiners KS, Hansen HP, et al. Human leukocyte antigen-B-associated transcript 3 is released from tumor cells and engages the NKp30 receptor on natural killer cells. Immunity. (2007) 27:965-74. doi: 10.1016/j.immuni.2007.10.010

87. Brandt CS, Baratin M, Yi EC, Kennedy J, Gao Z, Fox B, et al. The B7 family member B7-H6 is a tumor cell ligand for the activating natural killer cell receptor NKp30 in humans. J Exp Med. (2009) 206:1495503. doi: $10.1084 /$ jem.20090681

88. Hecht ML, Rosental B, Horlacher T, Hershkovitz O, De Paz JL, Noti C, et al. Natural cytotoxicity receptors NKp30, NKp44 and NKp46 bind to different heparan sulfate/heparin sequences. J Proteome Res. (2009) 8:71220. doi: 10.1021/pr800747c

89. Rosental B, Brusilovsky M, Hadad U, Oz D, Appel MY, Afergan F, et al. Proliferating cell nuclear antigen is a novel inhibitory ligand for the natural cytotoxicity receptor NKp44. J Immunol. (2011) 187:5693702. doi: $10.4049 /$ jimmunol.1102267

90. Baychelier F, Sennepin A, Ermonval M, Dorgham K, Debre P, Vieillard V. Identification of a cellular ligand for the natural cytotoxicity receptor NKp44. Blood. (2013) 122:2935-42. doi: 10.1182/blood-2013-03-4 89054

91. Narni-Mancinelli E, Gauthier L, Baratin M, Guia S, Fenis A, Deghmane $\mathrm{AE}$, et al. Complement factor $\mathrm{P}$ is a ligand for the natural killer cell-activating receptor NKp46. Sci Immunol. (2017) 2:eaam9628. doi: 10.1126/sciimmunol.aam 9628 
92. Barrow AD, Edeling MA, Trifonov V, Luo J, Goyal P, Bohl B, et al. Natural killer cells control tumor growth by sensing a growth factor. Cell. (2018) 172:534-48 e19. doi: 10.1016/j.cell.2017.11.037

93. Farnault L, Sanchez C, Baier C, Le Treut T, Costello RT. Hematological malignancies escape from $\mathrm{NK}$ cell innate immune surveillance: mechanisms and therapeutic implications. Clin Dev Immunol. (2012) 2012:421702. doi: 10.1155/2012/421702

94. Stojanovic A, Correia MP, Cerwenka A. Shaping of NK cell responses by the tumor microenvironment. Cancer Microenviron. (2013) 6:13546. doi: 10.1007/s12307-012-0125-8

95. Baginska J, Viry E, Paggetti J, Medves S, Berchem G, Moussay E, et al. The critical role of the tumor microenvironment in shaping natural killer cell-mediated anti-tumor immunity. Front Immunol. (2013) 4:490. doi: 10.3389/fimmu.2013.00490

96. Castriconi R, Cantoni C, Della Chiesa M, Vitale M, Marcenaro E, Conte $\mathrm{R}$, et al. Transforming growth factor beta 1 inhibits expression of NKp30 and NKG2D receptors: consequences for the NK-mediated killing of dendritic cells. Proc Natl Acad Sci USA. (2003) 100:41205. doi: 10.1073/pnas.0730640100

97. Della Chiesa M, Carlomagno S, Frumento G, Balsamo M, Cantoni $\mathrm{C}$, Conte $\mathrm{R}$, et al. The tryptophan catabolite L-kynurenine inhibits the surface expression of NKp46- and NKG2Dactivating receptors and regulates NK-cell function. Blood. (2006) 108:4118-25. doi: 10.1182/blood-2006-03-006700

98. Balsamo M, Scordamaglia F, Pietra G, Manzini C, Cantoni C, Boitano $\mathrm{M}$, et al. Melanoma-associated fibroblasts modulate NK cell phenotype and antitumor cytotoxicity. Proc Natl Acad Sci USA. (2009) 106:2084752. doi: 10.1073/pnas.0906481106

99. Pietra G, Manzini C, Rivara S, Vitale M, Cantoni C, Petretto A, et al. Melanoma cells inhibit natural killer cell function by modulating the expression of activating receptors and cytolytic activity. Cancer Res. (2012) 72:1407-15. doi: 10.1158/0008-5472.CAN-11-2544

100. Huergo-Zapico L, Parodi M, Cantoni C, Lavarello C, Fernandez-Martinez JL, Petretto A, et al. NK-cell editing mediates epithelial-to-mesenchymal transition via phenotypic and proteomic changes in melanoma cell lines. Cancer Res. (2018) 78:3913-25. doi: 10.1158/0008-5472.CAN-17-1891

101. Park A, Lee Y, Kim MS, Kang YJ, Park YJ, Jung H, et al. Prostaglandin E2 secreted by thyroid cancer cells contributes to immune escape through the suppression of natural killer (NK) cell cytotoxicity and NK cell differentiation. Front Immunol. (2018) 9:1859. doi: 10.3389/fimmu.2018.01859

102. Alvarez-Breckenridge CA, Yu J, Price R, Wojton J, Pradarelli J, Mao $\mathrm{H}$, et al. NK cells impede glioblastoma virotherapy through NKp30 and NKp46 natural cytotoxicity receptors. Nat Med. (2012) 18:182734. doi: $10.1038 / \mathrm{nm} .3013$

103. Yoo JY, Jaime-Ramirez AC, Bolyard C, Dai H, Nallanagulagari T, Wojton J, et al. Bortezomib Treatment Sensitizes Oncolytic HSV-1-Treated Tumors to NK Cell Immunotherapy. Clin Cancer Res. (2016) 22:526576. doi: 10.1158/1078-0432.CCR-16-1003

104. J GP, Levesque S, Workenhe ST, Gujar S, Le Boeuf F, D RC, et al. Trial Watch: Oncolytic viro-immunotherapy of hematologic and solid tumors. Oncoimmunology. (2018) 7:e1503032. doi: 10.1080/2162402X.2018.1503032

105. Rusakiewicz S, Perier A, Semeraro M, Pitt JM, Pogge von Strandmann E, Reiners KS, et al. NKp30 isoforms and NKp30 ligands are predictive biomarkers of response to imatinib mesylate in metastatic GIST patients. Oncoimmunology. (2017) 6:e1137418. doi: 10.1080/2162402X.2015.11 37418

106. Mantovani S, Oliviero B, Lombardi A, Varchetta S, Mele D, Sangiovanni A, et al. Deficient natural killer cell NKp30-mediated function and altered NCR3 splice variants in hepatocellular carcinoma. Hepatology. (2019) 69:1165-79. doi: 10.1002/hep.30235

107. Li L, Zhang Y, Li N, Feng L, Yao H, Zhang R, et al. Nidogen-1: a candidate biomarker for ovarian serous cancer. Jpn J Clin Oncol. (2015) 45:17682. doi: 10.1093/jjco/hyu187

108. Willumsen N, Bager CL, Leeming DJ, Bay-Jensen AC, Karsdal MA. Nidogen-1 degraded by Cathepsin $\mathrm{S}$ can be quantified in serum and is associated with non-small cell lung cancer. Neoplasia. (2017) 19:2718. doi: 10.1016/j.neo.2017.01.008
109. Costello RT, Sivori S, Marcenaro E, Lafage-Pochitaloff M, Mozziconacci MJ, Reviron D, et al. Defective expression and function of natural killer celltriggering receptors in patients with acute myeloid leukemia. Blood. (2002) 99:3661-7. doi: 10.1182/blood.V99.10.3661

110. Fauriat C, Just-Landi S, Mallet F, Arnoulet C, Sainty D, Olive D, et al. Deficient expression of NCR in NK cells from acute myeloid leukemia: evolution during leukemia treatment and impact of leukemia cells in NCRdull phenotype induction. Blood. (2007) 109:323-30. doi: 10.1182/blood-2005-08-027979

111. Costello RT, Knoblauch B, Sanchez C, Mercier D, Le Treut T, Sebahoun G. Expression of natural killer cell activating receptors in patients with chronic lymphocytic leukaemia. Immunology. (2012) 135:1517. doi: 10.1111/j.1365-2567.2011.03521.x

112. Platonova S, Cherfils-Vicini J, Damotte D, Crozet L, Vieillard V, Validire $\mathrm{P}$, et al. Profound coordinated alterations of intratumoral NK cell phenotype and function in lung carcinoma. Cancer Res. (2011) 71:541222. doi: 10.1158/0008-5472.CAN-10-4179

113. Carrega P, Morandi B, Costa R, Frumento G, Forte G, Altavilla G, et al. Natural killer cells infiltrating human nonsmall-cell lung cancer are enriched in CD56 ${ }^{\text {bright }} \mathrm{CD} 16^{-}$cells and display an impaired capability to kill tumor cells. Cancer. (2008) 112:863-75. doi: 10.1002/cncr.23239

114. Garcia-Iglesias T, Del Toro-Arreola A, Albarran-Somoza B, Del ToroArreola S, Sanchez-Hernandez PE, Ramirez-Duenas MG, et al. Low NKp30, NKp46 and NKG2D expression and reduced cytotoxic activity on NK cells in cervical cancer and precursor lesions. BMC Cancer. (2009) 9:186. doi: 10.1186/1471-2407-9-186

115. Rocca YS, Roberti MP, Arriaga JM, Amat M, Bruno L, Pampena MB, et al. Altered phenotype in peripheral blood and tumor-associated NK cells from colorectal cancer patients. Innate Immun. (2013) 19:7685. doi: 10.1177/1753425912453187

116. Pasero C, Gravis G, Guerin M, Granjeaud S, Thomassin-Piana J, Rocchi $\mathrm{P}$, et al. Inherent and tumor-driven immune tolerance in the prostate microenvironment impairs natural killer cell antitumor activity. Cancer Res. (2016) 76:2153-65. doi: 10.1158/0008-5472.CAN-15-1965

117. Cifaldi L, Locatelli F, Marasco E, Moretta L, Pistoia V. Boosting natural killer cell-based immunotherapy with anticancer drugs: a perspective. Trends $\mathrm{Mol}$ Med. (2017) 23:1156-75. doi: 10.1016/j.molmed.2017.10.002

118. Guillerey C, Huntington ND, Smyth MJ. Targeting natural killer cells in cancer immunotherapy. Nat Immunol. (2016) 17:1025-36. doi: 10.1038/ni.3518

119. Chiossone L, Vienne M, Kerdiles YM, Vivier E. Natural killer cell immunotherapies against cancer: checkpoint inhibitors and more. Semin Immunol. (2017) 31:55-63. doi: 10.1016/j.smim.2017.08.003

120. Souza-Fonseca-Guimaraes F, Cursons J, Huntington ND. The emergence of natural killer cells as a major target in cancer immunotherapy. Trends Immunol. (2019) 40:142-58. doi: 10.1016/j.it.2018.12.003

121. Matta J, Baratin M, Chiche L, Forel JM, Cognet C, Thomas G, et al. Induction of B7-H6, a ligand for the natural killer cell-activating receptor NKp30, in inflammatory conditions. Blood. (2013) 122:394404. doi: 10.1182/blood-2013-01-481705

122. Flodstrom-Tullberg M, Bryceson YT, Shi FD, Hoglund P, Ljunggren HG. Natural killer cells in human autoimmunity. Curr Opin Immunol. (2009) 21:634-40. doi: 10.1016/j.coi.2009.09.012

123. Wensveen FM, Jelencic V, Valentic S, Sestan M, Wensveen TT, Theurich $\mathrm{S}$, et al. NK cells link obesity-induced adipose stress to inflammation and insulin resistance. Nat Immunol. (2015) 16:376-85. doi: 10.1038/ni.3120

124. Gianchecchi E, Delfino DV, Fierabracci A. NK cells in autoimmune diseases: Linking innate and adaptive immune responses. Autoimmun Rev. (2018) 17:142-54. doi: 10.1016/j.autrev.2017.11.018

125. Gur C, Porgador A, Elboim M, Gazit R, Mizrahi S, Stern-Ginossar N, et al. The activating receptor NKp46 is essential for the development of type 1 diabetes. Nat Immunol. (2010) 11:121-8. doi: 10.1038/ni.1834

126. Berhani O, Glasner A, Kahlon S, Duev-Cohen A, Yamin R, Horwitz E, et al. Human anti-NKp46 antibody for studies of NKp46-dependent NK cell function and its applications for type 1 diabetes and cancer research. Eur J Immunol. (2019) 49:228-41. doi: 10.1002/eji.201847611

127. Siewiera J, Gouilly J, Hocine HR, Cartron G, Levy C, Al-Daccak R, et al. Natural cytotoxicity receptor splice variants orchestrate the distinct 
functions of human natural killer cell subtypes. Nat Commun. (2015) 6:10183. doi: 10.1038/ncomms 10183

128. Delahaye NF, Rusakiewicz S, Martins I, Menard C, Roux S, Lyonnet L, et al. Alternatively spliced NKp30 isoforms affect the prognosis of gastrointestinal stromal tumors. Nat Med. (2011) 17:700-7. doi: 10.1038/nm. 2366

129. Shemesh A, Brusilovsky M, Hadad U, Teltsh O, Edri A, Rubin E, et al. Survival in acute myeloid leukemia is associated with NKp44 splice variants. Oncotarget. (2016) 7:32933-45. doi: 10.18632/oncotarget.8782

130. Shemesh A, Kugel A, Steiner N, Yezersky M, Tirosh D, Edri A, et al. NKp44 and NKp30 splice variant profiles in decidua and tumor tissues: a comparative viewpoint. Oncotarget. (2016) 7:7091223. doi: $10.18632 /$ oncotarget.12292

131. Sivori S, Parolini S, Marcenaro E, Millo R, Bottino C, Moretta A. Triggering receptors involved in natural killer cell-mediated cytotoxicity against choriocarcinoma cell lines. Hum Immunol. (2000) 61:10558. doi: 10.1016/S0198-8859(00)00201-9

132. Vacca P, Cantoni C, Prato C, Fulcheri E, Moretta A, Moretta L, et al. Regulatory role of NKp44, NKp46, DNAM-1 and NKG2D receptors in the interaction between NK cells and trophoblast cells. Evidence for divergent functional profiles of decidual versus peripheral NK cells. Int Immunol. (2008) 20:1395-405. doi: 10.1093/intimm/dxn105

133. Vacca P, Montaldo E, Croxatto D, Loiacono F, Canegallo F, Venturini PL, et al. Identification of diverse innate lymphoid cells in human decidua. Mucosal Immunol. (2015) 8:254-64. doi: 10.1038/mi.2014.63

134. Moffett-King A. Natural killer cells and pregnancy. Nat Rev Immunol. (2002) 2:656-63. doi: 10.1038/nri886

135. Kopcow HD, Allan DS, Chen X, Rybalov B, Andzelm MM, Ge B, et al. Human decidual NK cells form immature activating synapses and are not cytotoxic. Proc Natl Acad Sci USA. (2005) 102:155638. doi: 10.1073/pnas. 0507835102

136. Vacca P, Chiossone L, Mingari MC, Moretta L. Heterogeneity of NK cells and other innate lymphoid cells in human and murine decidua. Front Immunol. (2019) 10:170. doi: 10.3389/fimmu.2019.00170

137. Hanna J, Goldman-Wohl D, Hamani Y, Avraham I, Greenfield C, Natanson-Yaron S, et al. Decidual NK cells regulate key developmental processes at the human fetal-maternal interface. Nat Med. (2006) 12:106574. doi: $10.1038 / \mathrm{nm} 1452$

138. Tripodi G, Poggi A, Orengo AM, Pella N, Vitale M, Sivori S, et al. Identification of a new surface molecule involved in the mechanism of cell to cell adhesion between human NK and tumor target cells. Cytotechnology. (1993) 11(Suppl 1):S109-11. doi: 10.1007/BF00746071

139. Moretta A, Bottino C, Tripodi G, Vitale M, Pende D, Morelli L, et al. Novel surface molecules involved in human NK cell activation and triggering of the lytic machinery. Int J Cancer Suppl. (1992) 7:6-10.

140. Sivori S, Parolini S, Falco M, Marcenaro E, Biassoni $\mathrm{R}$, Bottino $\mathrm{C}$, et al. 2B4 functions as a co-receptor in human NK cell activation. Eur J Immunol. (2000) 30:78793. doi: 10.1002/1521-4141(200003)30:3<787::AID-IMMU787>3.0.CO;2-I

141. Bottino C, Falco M, Parolini S, Marcenaro E, Augugliaro R, Sivori S, et al. NTB-A [correction of GNTB-A], a novel SH2D1A-associated surface molecule contributing to the inability of natural killer cells to kill Epstein-Barr virus-infected B cells in X-linked lymphoproliferative disease. J Exp Med. (2001) 194:235-46. doi: 10.1084/jem.194. 3.235

142. Falco M, Marcenaro E, Romeo E, Bellora F, Marras D, Vely F, et al. Homophilic interaction of NTBA, a member of the CD2 molecular family: induction of cytotoxicity and cytokine release in human NK cells. Eur $J$ Immunol. (2004) 34:1663-72. doi: 10.1002/eji.200424886

143. Marcenaro E, Augugliaro R, Falco M, Castriconi R, Parolini S, Sivori S, et al. CD59 is physically and functionally associated with natural cytotoxicity receptors and activates human NK cell-mediated cytotoxicity. Eur J Immunol. (2003) 33:3367-76. doi: 10.1002/eji.2003 24425

144. Vitale M, Falco M, Castriconi R, Parolini S, Zambello R, Semenzato $\mathrm{G}$, et al. Identification of NKp80, a novel triggering molecule expressed by human NK cells. Eur J Immunol. (2001) 31:23342. doi: 10.1002/1521-4141(200101)31:1<233::AID-IMMU233>3.0.CO;2-4
145. Boles KS, Nakajima H, Colonna M, Chuang SS, Stepp SE, Bennett $\mathrm{M}$, et al. Molecular characterization of a novel human natural killer cell receptor homologous to mouse 2B4. Tissue Antigens. (1999) 54:2734. doi: 10.1034/j.1399-0039.1999.540103.x

146. Kubin MZ, Parshley DL, Din W, Waugh JY, Davis-Smith T, Smith $\mathrm{CA}$, et al. Molecular cloning and biological characterization of NK cell activation-inducing ligand, a counterstructure for CD48. Eur J Immunol. (1999) 29:3466-77

147. Nakajima H, Cella M, Langen H, Friedlein A, Colonna M. Activating interactions in human NK cell recognition: the role of 2B4-CD48. Eur J Immunol. (1999) 29:1676-83.

148. Sayos J, Wu C, Morra M, Wang N, Zhang X, Allen D, et al. The X-linked lymphoproliferative-disease gene product SAP regulates signals induced through the co-receptor SLAM. Nature. (1998) 395:4629. doi: $10.1038 / 26683$

149. Parolini S, Bottino C, Falco M, Augugliaro R, Giliani S, Franceschini R, et al. $\mathrm{X}$-linked lymphoproliferative disease. $2 \mathrm{~B} 4$ molecules displaying inhibitory rather than activating function are responsible for the inability of natural killer cells to kill Epstein-Barr virus-infected cells. J Exp Med. (2000) 192:337-46. doi: 10.1084/jem.192.3.337

150. Nakajima H, Cella M, Bouchon A, Grierson HL, Lewis J, Duckett CS, et al. Patients with X-linked lymphoproliferative disease have a defect in 2B4 receptor-mediated NK cell cytotoxicity. Eur J Immunol. (2000) 30:330918. doi: 10.1002/1521-4141(200011)30:11<3309::AID-IMMU3309>3.0. $\mathrm{CO} ; 2-3$

151. Tangye SG, Phillips JH, Lanier LL, Nichols KE. Functional requirement for SAP in 2B4-mediated activation of human natural killer cells as revealed by the X-linked lymphoproliferative syndrome. J Immunol. (2000) 165:29326. doi: 10.4049/jimmunol.165.6.2932

152. Meazza R, Tuberosa C, Cetica V, Falco M, Loiacono F, Parolini S, et al. XLP1 inhibitory effect by $2 \mathrm{~B} 4$ does not affect DNAM-1 and NKG2D activating pathways in NK cells. Eur J Immunol. (2014) 44:152634. doi: 10.1002/eji.201344312

153. Meazza R, Falco M, Marcenaro S, Loiacono F, Canevali P, Bellora F, et al. Inhibitory $2 \mathrm{~B} 4$ contributes to NK cell education and immunological derangements in XLP1 patients. Eur J Immunol. (2017) 47:105161. doi: $10.1002 /$ eji.201646885

154. Sivori S, Falco M, Marcenaro E, Parolini S, Biassoni R, Bottino C, et al. Early expression of triggering receptors and regulatory role of 2B4 in human natural killer cell precursors undergoing in vitro differentiation. Proc Natl Acad Sci USA. (2002) 99:4526-31. doi: 10.1073/pnas.072065999

155. Vacca P, Pietra G, Falco M, Romeo E, Bottino C, Bellora F, et al. Analysis of natural killer cells isolated from human decidua: evidence that 2B4 (CD244) functions as an inhibitory receptor and blocks NK-cell function. Blood. (2006) 108:4078-85. doi: 10.1182/blood-2006-04-017343

156. Welte S, Kuttruff S, Waldhauer I, Steinle A. Mutual activation of natural killer cells and monocytes mediated by NKp80-AICL interaction. Nat Immunol. (2006) 7:1334-42. doi: 10.1038/ni1402

157. Freud AG, Keller KA, Scoville SD, Mundy-Bosse BL, Cheng S, Youssef $\mathrm{Y}$, et al. NKp80 defines a critical step during human natural killer cell development. Cell Rep. (2016) 16:379-91. doi: 10.1016/j.celrep.2016.05.095

158. Shibuya A, Campbell D, Hannum C, Yssel H, Franz-Bacon K, McClanahan T, et al. DNAM-1, a novel adhesion molecule involved in the cytolytic function of $\mathrm{T}$ lymphocytes. Immunity. (1996) 4:573-81. doi: 10.1016/S1074-7613(00)70060-4

159. Bottino C, Castriconi R, Pende D, Rivera P, Nanni M, Carnemolla B, et al. Identification of PVR (CD155) and Nectin-2 (CD112) as cell surface ligands for the human DNAM-1 (CD226) activating molecule. J Exp Med. (2003) 198:557-67. doi: 10.1084/jem.20030788

160. Pende D, Spaggiari GM, Marcenaro S, Martini S, Rivera P, Capobianco A, et al. Analysis of the receptor-ligand interactions in the natural killermediated lysis of freshly isolated myeloid or lymphoblastic leukemias: evidence for the involvement of the Poliovirus receptor (CD155) and Nectin-2 (CD112). Blood. (2005) 105:2066-73. doi: 10.1182/blood-2004-0 9-3548

161. Cerboni C, Fionda C, Soriani A, Zingoni A, Doria M, Cippitelli M, et al. The DNA damage response: a common pathway in the regulation of NKG2D and DNAM-1 ligand expression in normal, infected, and 
cancer cells. Front Immunol. (2014) 4:508. doi: 10.3389/fimmu.2013. 00508

162. Fionda C, Soriani A, Zingoni A, Santoni A, Cippitelli M. NKG2D and DNAM-1 ligands: molecular targets for NK cell-mediated immunotherapeutic intervention in multiple myeloma. Biomed Res Int. (2015) 2015:178698. doi: 10.1155/2015/178698

163. Fuchs A, Cella M, Giurisato E, Shaw AS, Colonna M. Cutting edge: CD96 (tactile) promotes NK cell-target cell adhesion by interacting with the poliovirus receptor (CD155). J Immunol. (2004) 172:39948. doi: 10.4049/jimmunol.172.7.3994

164. Stanietsky N, Simic H, Arapovic J, Toporik A, Levy O, Novik A, et al. The interaction of TIGIT with PVR and PVRL2 inhibits human NK cell cytotoxicity. Proc Natl Acad Sci USA. (2009) 106:1785863. doi: $10.1073 /$ pnas. 0903474106

165. Dougall WC, Kurtulus S, Smyth MJ, Anderson AC. TIGIT and CD96: new checkpoint receptor targets for cancer immunotherapy. Immunol Rev. (2017) 276:112-20. doi: 10.1111/imr.12518

166. Zhang Q, Bi J, Zheng X, Chen Y, Wang H, Wu W, et al. Blockade of the checkpoint receptor TIGIT prevents NK cell exhaustion and elicits potent anti-tumor immunity. Nat Immunol. (2018) 19:723-32. doi: 10.1038/s41590-018-0132-0

167. Banchereau J, Steinman RM. Dendritic cells and the control of immunity. Nature. (1998) 392:245-52. doi: 10.1038/32588

168. Ferlazzo G, Semino C, Melioli G. HLA class I molecule expression is up-regulated during maturation of dendritic cells, protecting them from natural killer cell-mediated lysis. Immunol Lett. (2001) 76:3741. doi: 10.1016/S0165-2478(00)00323-0

169. Ferlazzo G, Pack M, Thomas D, Paludan C, Schmid D, Strowig T, et al. Distinct roles of IL-12 and IL-15 in human natural killer cell activation by dendritic cells from secondary lymphoid organs. Proc Natl Acad Sci USA. (2004) 101:16606-11. doi: 10.1073/pnas.0407522101

170. Della Chiesa M, Vitale M, Carlomagno S, Ferlazzo G, Moretta L, Moretta A. The natural killer cell-mediated killing of autologous dendritic cells is confined to a cell subset expressing CD94/NKG2A, but lacking inhibitory killer Ig-like receptors. Eur J Immunol. (2003) 33:165766. doi: 10.1002/eji.200390042

171. Pende D, Castriconi R, Romagnani P, Spaggiari GM, Marcenaro S, Dondero A, et al. Expression of the DNAM-1 ligands, Nectin-2 (CD112) and poliovirus receptor (CD155), on dendritic cells: relevance for natural killer-dendritic cell interaction. Blood. (2006) 107:20306. doi: 10.1182/blood-2005-07-2696

172. Vitale M, Della Chiesa M, Carlomagno S, Pende D, Arico M, Moretta L, et al. NK-dependent DC maturation is mediated by TNFalpha and IFNgamma released upon engagement of the NKp30 triggering receptor. Blood. (2005) 106:566-71. doi: 10.1182/blood-2004-10-4035

173. Yu G, Xu X, Vu MD, Kilpatrick ED, Li XC. NK cells promote transplant tolerance by killing donor antigen-presenting cells. J Exp Med. (2006) 203:1851-8. doi: 10.1084/jem.20060603

174. Laffont S, Seillet C, Ortaldo J, Coudert JD, Guery JC. Natural killer cells recruited into lymph nodes inhibit alloreactive T-cell activation through perforin-mediated killing of donor allogeneic dendritic cells. Blood. (2008) 112:661-71. doi: 10.1182/blood-2007-10-120089

175. Terme M, Ullrich E, Delahaye NF, Chaput N, Zitvogel L. Natural killer celldirected therapies: moving from unexpected results to successful strategies. Nat Immunol. (2008) 9:486-94. doi: 10.1038/ni1580

176. Barrow AD, Colonna M. Tailoring Natural Killer cell immunotherapy to the tumour microenvironment. Semin Immunol. (2017) 31:30-6. doi: 10.1016/j.smim.2017.09.001

177. Fang F, Xiao W, Tian Z. NK cell-based immunotherapy for cancer. Semin Immunol. (2017) 31:37-54. doi: 10.1016/j.smim.2017.07.009

178. Don Yun H, Felices M, Vallera DA, Hinderlie P, Cooley S, Arock M, et al. Trispecific killer engager CD16xIL15xCD33 potently induces NK cell activation and cytotoxicity against neoplastic mast cells. Blood Adv. (2018) 2:1580-4. doi: 10.1182/bloodadvances.2018018176

179. Oei VYS, Siernicka M, Graczyk-Jarzynka A, Hoel HJ, Yang W, Palacios D, et al. Intrinsic functional potential of NK-cell subsets constrains retargeting driven by chimeric antigen receptors. Cancer Immunol Res. (2018) 6:46780. doi: 10.1158/2326-6066.CIR-17-0207
180. Zhang C, Oberoi P, Oelsner S, Waldmann A, Lindner A, Tonn T, et al. Chimeric antigen receptor-engineered NK-92 cells: an off-theshelf cellular therapeutic for targeted elimination of cancer cells and induction of protective antitumor immunity. Front Immunol. (2017) 8:533. doi: $10.3389 /$ fimmu. 2017.00533

181. Kalinski P, Nakamura Y, Watchmaker P, Giermasz A, Muthuswamy R, Mailliard RB. Helper roles of NK and CD8 + T cells in the induction of tumor immunity. Polarized dendritic cells as cancer vaccines. Immunol Res. (2006) 36:137-46. doi: 10.1385/IR:36:1:137

182. Ferlazzo G, Munz C. Dendritic cell interactions with NK cells from different tissues. J Clin Immunol. (2009) 29:265-73. doi: 10.1007/s10875-009-9283-y

183. Rydyznski CE, Waggoner SN. Boosting vaccine efficacy the natural (killer) way. Trends Immunol. (2015) 36:536-46. doi: 10.1016/j.it.2015.07.004

184. Becker I, Salaiza N, Aguirre M, Delgado J, Carrillo-Carrasco N, Kobeh LG, et al. Leishmania lipophosphoglycan (LPG) activates NK cells through toll-like receptor-2. Mol Biochem Parasitol. (2003) 130:6574. doi: 10.1016/S0166-6851(03)00160-9

185. Pisegna S, Pirozzi G, Piccoli M, Frati L, Santoni A, Palmieri G. p38 MAPK activation controls the TLR3-mediated up-regulation of cytotoxicity and cytokine production in human NK cells. Blood. (2004) 104:415764. doi: 10.1182/blood-2004-05-1860

186. Schmidt KN, Leung B, Kwong M, Zarember KA, Satyal S, Navas $\mathrm{TA}$, et al. APC-independent activation of NK cells by the Toll-like receptor 3 agonist double-stranded RNA. J Immunol. (2004) 172:13843. doi: 10.4049/jimmunol.172.1.138

187. Marcenaro E, Ferranti B, Falco M, Moretta L, Moretta A. Human NK cells directly recognize Mycobacterium bovis via TLR2 and acquire the ability to kill monocyte-derived DC. Int Immunol. (2008) 20:115567. doi: 10.1093/intimm/dxn073

188. Chalifour A, Jeannin P, Gauchat JF, Blaecke A, Malissard M, N'Guyen T, et al. Direct bacterial protein PAMP recognition by human NK cells involves TLRs and triggers alpha-defensin production. Blood. (2004) 104:177883. doi: 10.1182/blood-2003-08-2820

189. Hart OM, Athie-Morales V, O'Connor GM, Gardiner CM. TLR7/8mediated activation of human NK cells results in accessory cell-dependent IFN-gamma production. J Immunol. (2005) 175:1636-42. doi: 10.4049/jimmunol.175.3.1636

190. Esin S, Batoni G, Pardini M, Favilli F, Bottai D, Maisetta G, et al. Functional characterization of human natural killer cells responding to Mycobacterium bovis bacille Calmette-Guerin. Immunology. (2004) 112:14352. doi: 10.1111/j.1365-2567.2004.01858.x

191. Alter G, Suscovich TJ, Teigen N, Meier A, Streeck H, Brander C, et al. Singlestranded RNA derived from HIV-1 serves as a potent activator of NK cells. $J$ Immunol. (2007) 178:7658-66. doi: 10.4049/jimmunol.178.12.7658

192. Sivori S, Carlomagno S, Moretta L, Moretta A. Comparison of different CpG oligodeoxynucleotide classes for their capability to stimulate human NK cells. Eur J Immunol. (2006) 36:961-7. doi: 10.1002/eji.2005 35781

193. Sivori S, Falco M, Carlomagno S, Romeo E, Moretta L, Moretta A. Heterogeneity of TLR3 mRNA transcripts and responsiveness to poly (I:C) in human NK cells derived from different donors. Int Immunol. (2007) 19:1341-8. doi: 10.1093/intimm/dxm105

194. Sivori S, Falco M, Carlomagno S, Romeo E, Soldani C, Bensussan A, et al. A novel KIR-associated function: evidence that CpG DNA uptake and shuttling to early endosomes is mediated by KIR3DL2. Blood. (2010) 116:1637-47. doi: 10.1182/blood-2009-12-256586

195. Sivori S, Falco M, Moretta L, Moretta A. Extending killer Ig-like receptor function: from HLA class I recognition to sensors of microbial products. Trends Immunol. (2010) 31:289-94. doi: 10.1016/j.it.2010. 05.007

196. Ghazi B, Thonnart N, Bagot M, Bensussan A, Marie-Cardine A. KIR3DL2/CpG ODN interaction mediates Sezary syndrome malignant T cell apoptosis. J Invest Dermatol. (2015) 135:229-37. doi: 10.1038/jid.201 4.286

197. Kim YH, Girardi M, Duvic M, Kuzel T, Link BK, Pinter-Brown L, et al. Phase I trial of a Toll-like receptor 9 agonist, PF-3512676 (CPG 7909), in patients with treatment-refractory, cutaneous T-cell lymphoma. J Am Acad Dermatol. (2010) 63:975-83. doi: 10.1016/j.jaad.2009.12.052 
198. Matsumoto M, Tatematsu M, Nishikawa F, Azuma M, Ishii N, MoriiSakai A, et al. Defined TLR3-specific adjuvant that induces NK and CTL activation without significant cytokine production in vivo. Nat Commun. (2015) 6:6280. doi: 10.1038/ncomms7280

199. Circelli L, Tornesello M, Buonaguro FM, Buonaguro L. Use of adjuvants for immunotherapy. Hum Vaccin Immunother. (2017) 13:1774-7. doi: 10.1080/21645515.2017.1321725

200. Mandelboim O, Lieberman N, Lev M, Paul L, Arnon TI, Bushkin Y, et al. Recognition of haemagglutinins on virus-infected cells by NKp46 activates lysis by human NK cells. Nature. (2001) 409:1055-60. doi: 10.1038/35059110

201. Arnon TI, Lev M, Katz G, Chernobrov Y, Porgador A, Mandelboim O. Recognition of viral hemagglutinins by NKp44 but not by NKp30. Eur J Immunol. (2001) 31:26809. doi: 10.1002/1521-4141(200109)31:9<2680::AID-IMMU2680>3.0.CO;2-A

202. Brusilovsky M, Rosental B, Shemesh A, Appel MY, Porgador A. Human NK cell recognition of target cells in the prism of natural cytotoxicity receptors and their ligands. J Immunotoxicol. (2012) 9:26774. doi: 10.3109/1547691X.2012.675366

203. Arnon TI, Achdout H, Levi O, Markel G, Saleh N, Katz G, et al. Inhibition of the NKp30 activating receptor by pp65 of human cytomegalovirus. Nat Immunol. (2005) 6:515-23. doi: 10.1038/ni1190

204. Pallmer K, Barnstorf I, Baumann NS, Borsa M, Jonjic S, Oxenius A. NK cells negatively regulate CD8 T cells via natural cytotoxicity receptor (NCR) 1 during LCMV infection. PLoS Pathog. (2019) 15:e1007725. doi: 10.1371/journal.ppat.1007725

205. De Maria A, Fogli M, Costa P, Murdaca G, Puppo F, Mavilio D, et al. The impaired NK cell cytolytic function in viremic HIV-1 infection is associated with a reduced surface expression of natural cytotoxicity receptors (NKp46, NKp30 and NKp44). Eur J Immunol. (2003) 33:24108. doi: 10.1002/eji.200324141

206. Mavilio D, Benjamin J, Daucher M, Lombardo G, Kottilil S, Planta MA, et al. Natural killer cells in HIV-1 infection: dichotomous effects of viremia on inhibitory and activating receptors and their functional correlates. Proc Natl Acad Sci USA. (2003) 100:15011-6. doi: 10.1073/pnas.2336091100

207. Marras F, Nicco E, Bozzano F, Di Biagio A, Dentone C, Pontali E, et al. Natural killer cells in HIV controller patients express an activated effector phenotype and do not up-regulate NKp44 on IL-2 stimulation. Proc Natl Acad Sci USA. (2013) 110:11970-5. doi: 10.1073/pnas.1302090110

208. Marras F, Casabianca A, Bozzano F, Ascierto ML, Orlandi C, Di Biagio A, et al. Control of the HIV-1 DNA reservoir is associated in vivo and in vitro with NKp46/NKp30 (CD335 CD337) inducibility and interferon gamma production by transcriptionally unique NK cells. J Virol. (2017) 91:e00647-17. doi: 10.1128/JVI.00647-17

209. Alter G, Jost S, Rihn S, Reyor LL, Nolan BE, Ghebremichael M, et al. Reduced frequencies of NKp30+NKp46+, CD161+, and NKG2D+ NK cells in acute HCV infection may predict viral clearance. J Hepatol. (2011) 55:278-88. doi: 10.1016/j.jhep.2010.11.030

210. Bozzano F, Picciotto A, Costa P, Marras F, Fazio V, Hirsch I, et al. Activating NK cell receptor expression/function (NKp30, NKp46, DNAM-1) during chronic viraemic $\mathrm{HCV}$ infection is associated with the outcome of combined treatment. Eur J Immunol. (2011) 41:2905-14. doi: 10.1002/eji.201041361

211. Ascierto ML, Bozzano F, Bedognetti D, Marras F, Schechterly C, Matsuura $\mathrm{K}$, et al. Inherent transcriptional signatures of NK cells are associated with response to IFNalpha + rivabirin therapy in patients with Hepatitis C Virus. J Transl Med. (2015) 13:77. doi: 10.1186/s12967-015-0428-x

212. Fogli M, Costa P, Murdaca G, Setti M, Mingari MC, Moretta L, et al. Significant NK cell activation associated with decreased cytolytic function in peripheral blood of HIV-1-infected patients. Eur J Immunol. (2004) 34:2313-21. doi: 10.1002/eji.200425251

213. Mavilio D, Lombardo G, Benjamin J, Kim D, Follman D, Marcenaro E, et al. Characterization of CD56-/CD16+ natural killer (NK) cells: a highly dysfunctional NK subset expanded in HIV-infected viremic individuals. Proc Natl Acad Sci USA. (2005) 102:2886-91. doi: 10.1073/pnas.04098 72102

214. Mavilio D, Lombardo G, Kinter A, Fogli M, La Sala A, Ortolano S, et al. Characterization of the defective interaction between a subset of natural killer cells and dendritic cells in HIV-1 infection. J Exp Med. (2006) 203:2339-50. doi: 10.1084/jem.20060894
215. Farnault L, Chambost H, Michel G, Thuret I, de Saint Basile G, Fischer A, et al. Persistence of natural killer cells with expansion of a hypofunctional CD56-CD16+KIR+NKG2C+ subset in a patient with atypical Janus kinase 3-deficient severe combined immunodeficiency. J Allergy Clin Immunol. (2013) 131:1230-3. doi: 10.1016/j.jaci.2012.08.047

216. Bjorkstrom NK, Ljunggren HG, Sandberg JK. CD56 negative NK cells: origin, function, and role in chronic viral disease. Trends Immunol. (2010) 31:401-6. doi: 10.1016/j.it.2010.08.003

217. Gonzalez VD, Falconer K, Bjorkstrom NK, Blom KG, Weiland O, Ljunggren $\mathrm{HG}$, et al. Expansion of functionally skewed CD56-negative NK cells in chronic hepatitis $\mathrm{C}$ virus infection: correlation with outcome of pegylated IFN-alpha and ribavirin treatment. J Immunol. (2009) 183:66128. doi: 10.4049/jimmunol.0901437

218. Bjorkstrom NK, Lindgren T, Stoltz M, Fauriat C, Braun M, Evander M, et al. Rapid expansion and long-term persistence of elevated NK cell numbers in humans infected with hantavirus. J Exp Med. (2011) 208:1321. doi: 10.1084 /jem. 20100762

219. Schlums H, Jung M, Han H, Theorell J, Bigley V, Chiang SC, et al. Adaptive NK cells can persist in patients with GATA2 mutation depleted of stem and progenitor cells. Blood. (2017) 129:1927-39. doi: 10.1182/blood-2016-08-734236

220. Lopez-Botet M, Muntasell A, Vilches C. The CD94/NKG2C+ NK-cell subset on the edge of innate and adaptive immunity to human cytomegalovirus infection. Semin Immunol. (2014) 26:145-51. doi: 10.1016/j.smim.2014.03.002

221. Tesi B, Schlums H, Cichocki F, Bryceson YT. Epigenetic regulation of adaptive NK cell diversification. Trends Immunol. (2016) 37:45161. doi: 10.1016/j.it.2016.04.006

222. Rolle A, Brodin P. Immune adaptation to environmental influence: the case of NK cells and HCMV. Trends Immunol. (2016) 37:23343. doi: 10.1016/j.it.2016.01.005

223. Guma M, Angulo A, Vilches C, Gomez-Lozano N, Malats N, Lopez-Botet M. Imprint of human cytomegalovirus infection on the NK cell receptor repertoire. Blood. (2004) 104:3664-71. doi: 10.1182/blood-2004-05-2058

224. Guma M, Budt M, Saez A, Brckalo T, Hengel H, Angulo A, et al. Expansion of CD94/NKG2C+ NK cells in response to human cytomegalovirus-infected fibroblasts. Blood. (2006) 107:3624-31. doi: 10.1182/blood-2005-09-3682

225. Della Chiesa M, Falco M, Podesta M, Locatelli F, Moretta L, Frassoni F, et al. Phenotypic and functional heterogeneity of human NK cells developing after umbilical cord blood transplantation: a role for human cytomegalovirus? Blood. (2012) 119:399-410. doi: 10.1182/blood-2011-08-372003

226. Della Chiesa M, Muccio L, Moretta A. CMV induces rapid NK cell maturation in HSCT recipients. Immunol Lett. (2013) 155:113. doi: 10.1016/j.imlet.2013.09.020

227. Muccio L, Bertaina A, Falco M, Pende D, Meazza R, Lopez-Botet M, et al. Analysis of memory-like natural killer cells in human cytomegalovirusinfected children undergoing alphabeta $+\mathrm{T}$ and $\mathrm{B}$ cell-depleted hematopoietic stem cell transplantation for hematological malignancies. Haematologica. (2016) 101:371-81. doi: 10.3324/haematol.2015.134155

228. Muccio L, Falco M, Bertaina A, Locatelli F, Frassoni F, Sivori S, et al. Late development of fcepsilonrgamma(neg) adaptive natural killer cells upon human cytomegalovirus reactivation in umbilical cord blood transplantation recipients. Front Immunol. (2018) 9:1050. doi: 10.3389/fimmu.2018.01050

229. Foley B, Cooley S, Verneris MR, Pitt M, Curtsinger J, Luo X, et al. Cytomegalovirus reactivation after allogeneic transplantation promotes a lasting increase in educated NKG2C+ natural killer cells with potent function. Blood. (2012) 119:2665-74. doi: 10.1182/blood-2011-10386995

230. Foley B, Cooley S, Verneris MR, Curtsinger J, Luo X, Waller EK, et al. Human cytomegalovirus (CMV)-induced memory-like NKG2C(+) NK cells are transplantable and expand in vivo in response to recipient CMV antigen. J Immunol. (2012) 189:5082-8. doi: 10.4049/jimmunol.1201964

231. Schlums H, Cichocki F, Tesi B, Theorell J, Beziat V, Holmes TD, et al. Cytomegalovirus infection drives adaptive epigenetic diversification of NK cells with altered signaling and effector function. Immunity. (2015) 42:44356. doi: 10.1016/j.immuni.2015.02.008

232. Lee J, Zhang T, Hwang I, Kim A, Nitschke L, Kim M, et al. Epigenetic modification and antibody-dependent expansion of memory-like NK cells 
in human cytomegalovirus-infected individuals. Immunity. (2015) 42:43142. doi: 10.1016/j.immuni.2015.02.013

233. Cichocki F, Taras E, Chiuppesi F, Wagner JE, Blazar BR, Brunstein C, et al. Adaptive NK cell reconstitution is associated with better clinical outcomes. JCI insight. (2019) 4:125553. doi: 10.1172/jci.insight.125553

234. Hammer Q, Ruckert T, Borst EM, Dunst J, Haubner A, Durek P, et al. Peptide-specific recognition of human cytomegalovirus strains controls adaptive natural killer cells. Nat Immunol. (2018) 19:45363. doi: 10.1038/s41590-018-0082-6

235. Locatelli F, Pende D, Falco M, Della Chiesa M, Moretta A, Moretta L. NK Cells mediate a crucial graft-versus-leukemia effect in haploidenticalHSCT to cure high-risk acute leukemia. Trends Immunol. (2018) 39:57790. doi: 10.1016/j.it.2018.04.009

236. Lanier LL, Ruitenberg JJ, Phillips JH. Functional and biochemical analysis of CD16 antigen on natural killer cells and granulocytes. J Immunol. (1988) 141:3478-85.

237. Mathew PA, Garni-Wagner BA, Land K, Takashima A, Stoneman E, Bennett $\mathrm{M}$, et al. Cloning and characterization of the $2 \mathrm{~B} 4$ gene encoding a molecule associated with non-MHC-restricted killing mediated by activated natural killer cells and T cells. J Immunol. (1993) 151:5328-37.

238. Vitale M, Della Chiesa M, Carlomagno S, Romagnani C, Thiel A, Moretta L, et al. The small subset of CD56brightCD16- natural killer cells is selectively responsible for both cell proliferation and interferon-gamma production upon interaction with dendritic cells. Eur J Immunol. (2004) 34:171522. doi: 10.1002/eji.200425100

239. Ghiringhelli F, Menard C, Terme M, Flament C, Taieb J, Chaput N, et al. $\mathrm{CD} 4+\mathrm{CD} 25+$ regulatory $\mathrm{T}$ cells inhibit natural killer cell functions in a transforming growth factor-beta-dependent manner. J Exp Med. (2005) 202:1075-85. doi: 10.1084/jem.20051511

240. Marcenaro E, Della Chiesa M, Bellora F, Parolini S, Millo R, Moretta L, et al. IL-12 or IL-4 prime human NK cells to mediate functionally divergent interactions with dendritic cells or tumors. J Immunol. (2005) 174:39928. doi: 10.4049/jimmunol.174.7.3992
241. Sanos SL, Bui VL, Mortha A, Oberle K, Heners C, Johner C, et al. RORgammat and commensal microflora are required for the differentiation of mucosal interleukin 22-producing NKp46+ cells. Nat Immunol. (2009) 10:83-91. doi: 10.1038/ni.1684

242. Magri G, Muntasell A, Romo N, Saez-Borderias A, Pende D, Geraghty DE, et al. NKp46 and DNAM-1 NK-cell receptors drive the response to human cytomegalovirus-infected myeloid dendritic cells overcoming viral immune evasion strategies. Blood. (2011) 117:848-56. doi: 10.1182/blood-2010-08-3 01374

243. Shemer-Avni Y, Kundu K, Shemesh A, Brusilovsky M, Yossef R, Meshesha M, et al. Expression of NKp46 splice variants in nasal lavage following respiratory viral infection: domain 1-negative isoforms predominate and manifest higher activity. Front Immunol. (2017) 8:161. doi: 10.3389/fimmu.2017.00161

244. Pesce S, Greppi M, Tabellini G, Rampinelli F, Parolini S, Olive D, et al. Identification of a subset of human natural killer cells expressing high levels of programmed death 1: a phenotypic and functional characterization. J Allergy Clin Immunol. (2017) 139:335-46 e3. doi: 10.1016/j.jaci.2016. 04.025

Conflict of Interest Statement: The authors declare that the research was conducted in the absence of any commercial or financial relationships that could be construed as a potential conflict of interest.

Copyright (C) 2019 Vitale, Cantoni, Della Chiesa, Ferlazzo, Carlomagno, Pende, Falco, Pessino, Muccio, De Maria, Marcenaro, Moretta and Sivori. This is an open-access article distributed under the terms of the Creative Commons Attribution License (CC BY). The use, distribution or reproduction in other forums is permitted, provided the original author(s) and the copyright owner(s) are credited and that the original publication in this journal is cited, in accordance with accepted academic practice. No use, distribution or reproduction is permitted which does not comply with these terms. 